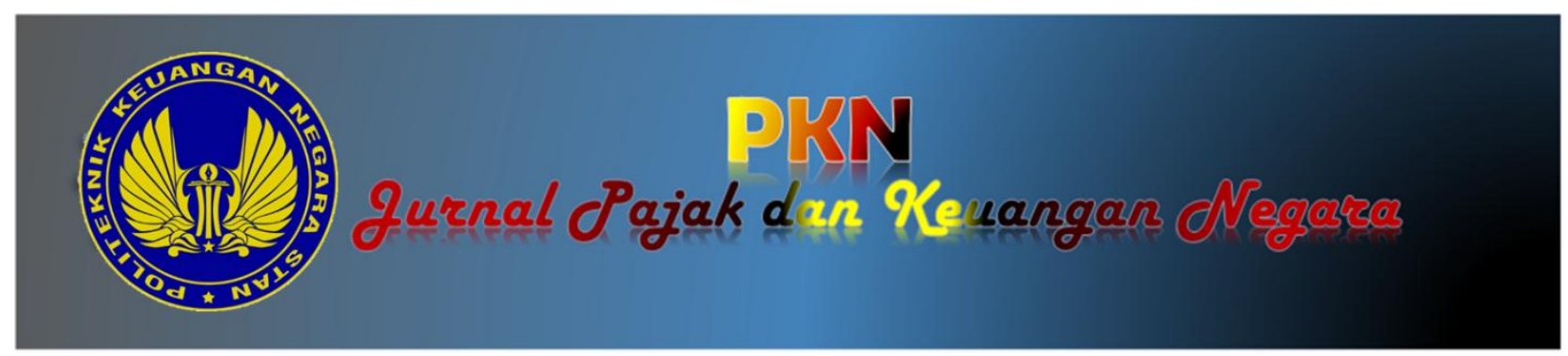

\title{
DESAIN KERANGKA KONSEPTUAL BALANCED SCORE CARD PADA LEMBAGA RISET PEMERINTAH
}

\author{
Resi Ariyasa Qadri \\ Politeknik Keuangan Negara STAN \\ Rifqie Jauhari \\ Lembaga Ilmu Pengetahuan Indonesia
}

Alamat Korespondensi: resi.ariyasa@pknstan.ac.id.

INFORMASI ARTIKEL

Diterima Pertama

[19 Maret 2020]

Dinyatakan Diterima

[20 Maret 2020]

\section{KATA KUNCl:}

Balanced Scorecard, Pengukuran Kinerja, LIPI, Riset Studi Kasus, Indonesia.

\section{KLASIFIKASI JEL:}

[Untuk klasifikasi keywords menggunakan standard JEL codes yang dapat diakses pada http://www.aeaweb.org/jel/guide/jel.php]. [Calibri, 9, Regular].

\begin{abstract}
ABSTRAK
This research aims to formulate a conceptual model of balanced scorecard for public sector organization, especially for the Indonesian Institute of Sciences, based on international best practices. Key success factors for implementating the model and the challenges are the other objectices of this research. It employed explanatory case study research as methodology to achieve the research objectives. 2 main protocols for collecting empirical evidences, namely document analysis and archival records study, were carried out for later scrutiny using explanation building techniques and analytic generalization as method of analysis. The results of this research not only display, but also define what a balanced scorecard model for public sector organization should be looked like as the model aligns with organizational characteristics and strategic plan. In order to achieving a successful implementation, continuous improvement should be applied to the model. No less important is to obtain top management support to boost the full implementation of the model so that it will improve LIPI's performance as well as its goals achievement.
\end{abstract}

Penelitian ini dilakukan untuk merumuskan model konseptual balanced scorecard bagi organisasi sektor publik, dalam hal ini Lembaga Ilmu Pengetahuan Indonesia, berdasarkan praktik terbaik di dunia internasional, serta apa saja faktor yang menjadi kunci sukses implementasi model tersebut dan apa saja tantangan implementasinya. Metodologi riset studi kasus eksplanatori digunakan untuk untuk mencapai tujuan penelitian tersebut. 2 protokol utama untuk pengumpulan bukti empiris, analisis artikel seminal dan studi dokumen internal, dijalankan untuk kemudian dielaborasi dengan menggunakan teknik explanation building dan analytic generalization. Hasil penelitian ini tidak hanya menyuguhkan, bahkan juga mendefinisikan seperti apa bentuk model konseptual balanced scorecard yang selaras dengan karakteristik organisasi dan sasaran strategis yang hendak dicapai dalam 5 tahun terakhir. Pengembangan yang berkelanjutan terhadap model konseptual tersebut agar sesuai dengan perkembangan organisasi adalah syarat utama keberhasilan implementasi model tersebut di LIPI. Yang tidak kalah pentingnya adalah memperoleh dukungan manajemen puncak untuk menerapkan model tersebut demi memperbaiki kinerja dan arah tujuan organisasi. 


\section{PENDAHULUAN}

Beberapa dekade sejak tercetusnya reformasi di bidang pengelolaan organisasi sektor publik (NPM) yang diusung oleh Margaret Tatcher pada akhir 1980an dan awal 1990-an, organisasi sektor publik, termasuk pemerintah, di seluruh dunia menghadapi tekanan yang semakin besar untuk menerapkan sistem manajemen kinerja yang efektif (Boston, Martin, Pallot, \& Walsh, 1996; Hood, 1995). Masyarakat pun semakin menuntut transparansi dan akuntabilitas yang lebih besar sehubungan dengan penggunaan dana publik oleh organisasi tersebut (Balabonienè \& Večerskienè, 2015). Hal ini kemudian mendorong organisasi sektor publik untuk berlombalomba dalam menerapkan praktik manajemen kinerja sektor swasta sebagai sarana potensial untuk meningkatkan dan mempertanggungjawabkan akuntabilitas kinerjanya (Jackson \& Lapsley, 2003; Lapsley \& Wright, 2004; Perera, McKinnon, \& Harrison, 2003). Saat ini, berbagai terobosan untuk mendukung peralihan institutional logic dari praktik manajemen kinerja sektor publik telah dilakukan (Balabonienė \& Večerskienė, 2015). Perumusan target kinerja dari organisasi sektor publik harus selaras dengan tujuan strategisnya.

Salah satu alat yang secara luas digunakan untuk memastikan agar perumusan target manajemen kinerja tidak melenceng jauh dari tujuan strategis organisasi adalah balanced scorecard - BSC (Kollberg \& Elg, 2011; Modell, 2004; Rabbani et al., 2007). Secara umum, BSC mampu menyajikan perspektif multidimensi dari kinerja suatu organisasi untuk berbagai pemangku kepentingan (Kaplan, 2009; Niven, 2006, 2008). Hal ini selaras dengan apa yang dibutuhkan oleh organisasi sektor publik terkait cara pengukuran kinerjanya (Bryson, 2010; Bryson, Crosby, \& Bryson, 2009; Wilson, Hagarty, \& Gauthier, 2004)). BSC menitikberatkan pada perumusan indikator kinerja utama (KPI) yang langsung diturunkan dari tujuan strategis organisasi. Apabila BSC tersebut diimplementasikan, perhatian manajemen pun akan teralihkan secara otomatis pada (1) hal-hal penting yang akan meningkatkan output organisasi, dan (2) informasi capaian kinerja yang menghubungkan antara KPI dengan output yang ingin dicapai (Kaplan, 2009). BSC telah digunakan secara luas sebagai alat pengukuran kinerja yang andal di dunia bisnis (Kald \& Nilsson, 2000; Neely, 2005). Meski awalnya hanya digunakan sebagai alat pengukuran kinerja organisasi yang bersifat multidimensi (Johnson \& Kaplan, 1987; Kaplan \& Norton, 1992), sekarang BSC memiliki cakupan yang lebih luas lagi, yaitu sebagai bagian penting dari sistem manajemen kinerja organisasi (Kaplan \& Norton, 2001a, 2001b).

Namun, terlepas dari adanya manfaat yang jelas yang mampu BSC berikan untuk meningkatkan kualitas dari sistem manajemen kinerja organisasi, hanya sedikit literatur empiris yang membahas tentang implementasi dan outcome dari BSC pada organisasi sektor publik (Northcott \& Ma'amoraTaulapapa, 2012). Secara umum, beberapa studi terdahulu tentang BSC hanya menitikberatkan pada implementasi BSC pada organisasi sektor swasta (Bourne, Kennerley, \& Franco-Santos, 2005; Cohen, Thiraios, \& Kandilorou, 2008; Davis \& Albright, 2004; Hoque \& James, 2000; Lipe \& Salterio, 2002). Beberapa studi lainnya berkesimpulan bahwa sistem manajemen kinerja berbasis BSC yang banyak diimplementasikan di organisasi sektor swasta didasarkan pada asumsi bahwa terdapat hubungan sebab akibat antara empat dimensi BSC, yaitu inovasi dan pembelajaran, proses bisnis internal, pelanggan, serta keuangan (Davis \& Albright, 2004; Inamdar \& Kaplan, 2002; Ittner, Larcker, \& Randall, 2003; Striteska, 2012). Meski demikian, bukan berarti BSC tidak dapat diaplikasikan pada organisasi sektor publik (Niven, 2008). Sebaliknya, beberapa studi terdahulu malah menyarankan bahwa pada dasarnya, BSC memiliki utilitas untuk diterapkan pada organisasi sektor publik karena sifat multidimensi-nya sangat berguna dalam menangkap aspek kinerja nonkeuangan (Chan, 2004; Greatbanks \& Tapp, 2007; Wilson et al., 2004).

Bahkan, beberapa area sektor publik telah mendapatkan perhatian lebih banyak dibandingkan area sektor publik lainnya dari para peneliti. Di bidang kesehatan, misalnya, studi implementasi BSC telah dilakukan di berbagai negara, termasuk Amerika Serikat, Belanda, Inggris, Kanada, Selandia Baru, Singapura, dan Swedia (Lars-Göran Aidemark \& Funck, 2009; Braam, Benders, \& Heusinkveld, 2007; Chang, 2007; Chow-Chua \& Goh, 2002; Libby, Salterio, \& Webb, 2004; Northcott \& France, 2005; Pallot, 2001). Di Indonesia sendiri, area sektor publik yang mendapatkan perhatian lebih adalah bidang pengelolaan pemerintah pusat, yaitu Kementerian Keuangan (Budiarso, 2013), Kementerian Kelautan dan Perikanan (Nurcholis, Satria, \& Maulana, 2017), dan Kementerian Dalam Negeri (Narutomo, 2012), bidang pengelolaan pemerintah daerah, yaitu Pemerintah Provinsi Kepulauan Riau (Gunarsih, Saleh, Syukron D. W., \& Deros, 2016) dan Pemerintah Provinsi Kalimantan Timur (Nor, 2012), bidang pendidikan, yaitu Universitas Kristen Satya Wacana (Tanone, Manongga, \& Tambotoh, 2013). Sementara, area sektor publik lainnya relatif diabaikan. Lembaga pemerintah setingkat kementerian termasuk salah satu area sektor publik yang belum banyak mendapat perhatian para peneliti BSC.

Lembaga Ilmu Pengetahuan Indonesia (LIPI) adalah salah satu lembaga pemerintah setingkat kementerian yang mengurusi bidang riset nasional. Namun, lembaga penting tersebut ternyata belum memiliki standar pengukuran kinerja yang memadai (http://lipi.go.id/). Peran LIPI sangat vital dalam pengembangan riset dan ilmu pengetahuan di Indonesia. Oleh karenanya, ketiadaan standar pengukuran kinerja yang memadai akan menghambat proses pencapaian tujuan strategis (Fernandez, Zainol, \& Ahmad, 2017). Untuk mengatasi masalah tersebut, penggunaan BSC dapat memberikan nilai tambah bagi LIPI dalam bentuk peningkatan kualitas dari sistem manajemen kinerjanya. Melalui implementasi BSC, mau tidak mau LIPI harus merumuskan KPI yang merefleksikan tujuan dari 
setiap pemangku kepentingan. Dengan demikian, mengingat vitalnya peran LIPI dalam pengembangan riset dan ilmu pengetahuan di Indonesia serta belum adanya studi empiris yang terpublikasi secara ilmiah pada jurnal nasional maupun internasional terkait pengembangan BSC pada lembaga riset setingkat kementerian, penelitian ini berorientasi untuk mengisi kesenjangan penelitian, baik yang bersifat praktis maupun teoretis. Kesenjangan penelitian tersebut kemudian mendorong peneliti untuk merumuskan tiga pertanyaan utama yang mendukung penelitian ini: (1) seperti apa desain model konseptual BSC sebagai alat pengukuran kinerja bagi LIPI? (2) faktorfaktor apa saja yang berkontribusi terhadap keberhasilan implementasi BSC di LIPI? (3) apa saja tantangan dalam implementasi BSC di LIPI?

Penelitian ini merupakan studi empiris terkait pengembangan model BSC dalam konteks sektor publik, khususnya pada lembaga riset setingkat kementerian. Ada 2 tujuan yang akan dipenuhi melalui penelitian ini, yaitu pertama, untuk memperluas cakupan penelitian BSC pada area sektor publik yang relatif kurang mendapat perhatian peneliti, yaitu lembaga riset nasional setingkat kementerian, LIPI. Lembaga tersebut bertanggung jawab untuk mencapai berbagai tujuan atas nama berbagai kelompok pemangku kepentingan dan, seperti organisasi sektor publik lainnya, telah berada di bawah tekanan untuk meningkatkan akuntabilitas kinerja (Poister \& Streib, 1999; Wisniewski \& Ólafsson, 2004). Tujuan kedua dari penelitian ini adalah untuk menganalisis faktor-faktor yang mendukung dan menghambat implementasi BSC pada organisasi sektor publik.

Penelitian ini mengadaptasi kerangka pemikiran riset studi kasus (Yin, 1977, 1981, 2014, 2018; Yin \& Kaftarian, 1997; Yin \& Lucas, 1973) sebagai metodologi untuk memenuhi tiga tujuan penelitian yang telah dijelaskan sebelumnya. Sistematika penulisan artikel ini disusun sebagai berikut: pertama, peneliti menyajikan kerangka teori yang membahas tentang manfaat, masalah, dan tantangan dalam menerapkan BSC pada organisasi sektor publik. Setelah itu, dijelaskan tentang metode penelitian yang digunakan. Kemudian, dijabarkan tentang deskripsi objek studi untuk memberikan latar belakang kontekstual terkait desain model BSC yang tepat bagi objek studi. Bagian selanjutnya menyajikan pembahasan untuk menjawab 3 pertanyaan penelitian. Bagian akhir dari artikel ini menyajikan tentang kesimpulan dan implikasi penelitian.

\section{KERANGKA TEORI}

\subsection{Balance Scorecard Organisasi Nirlaba: Perspektif Keuangan Bukan Tujuan Utama}

Kaplan dan Norton (1996) menjelaskan bahwa "seluruh hubungan sebab-akibat dapat ditetapkan sebagai vektor vertikal yang berhubungan dengan empat perspektif balanced scorecard" (Gambar 1). Hubungan sebab akibat ini menunjukkan bahwa tindakan manajerial yang diarahkan untuk meningkatkan hasil pada tiga perspektif pertama (inovasi dan pembelajaran, proses bisnis internal, dan pelanggan) pada akhirnya akan mendorong peningkatan kinerja di perspektif keempat, yaitu keuangan (Butler, Letza, \& Neale, 1997). Oleh karenanya, dapat diketahui dengan jelas bahwa BSC menempatkan perspektif keuangan sebagai titik akhir dari tujuan sistem manajemen kinerja organisasi (Kaplan, 2009; Neely, 2005). Hal ini tidak konsisten dengan tujuan sebagian besar organisasi sektor publik (Niven, 2006, 2008). Kaplan dan Norton (2001a) menjelaskan lebih lanjut bahwa BSC awalnya memang dirancang untuk membantu perusahaan dalam meningkatkan laba, tetapi bukan berarti BSC tidak dapat digunakan oleh organisasi sektor publik.

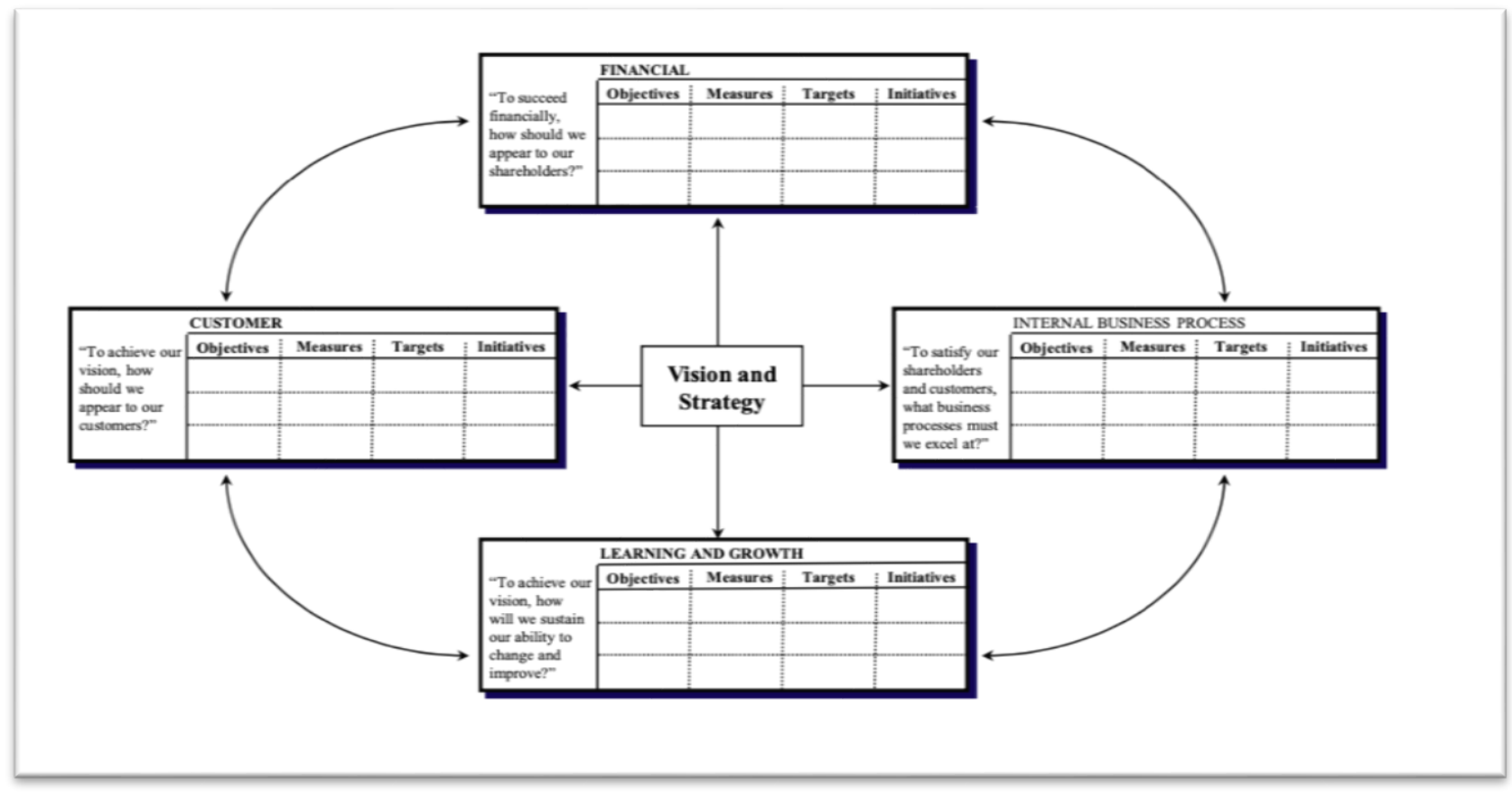


BSC dapat diimplementasikan pada organisasi sektor publik dengan melakukan sedikit penyesuaian terhadap kerangka konseptualnya, yaitu menempatkan perspektif pelanggan pada bagian atas hierarki, bukan perspektif keuangan (Niven, 2006; Northcott \& France, 2005). Disamping itu, BSC memiliki fungsi ganda dalam konteks sektor publik, yaitu pertama, sebagai instrumen pengukuran kinerja, dan kedua, sebagai sarana untuk meningkatkan akuntabilitas dan pertanggungjawaban kinerja organisasi (Kaplan \& Norton, 1992). Adanya fungsi ganda BSC dalam konteks sektor publik sejalan dengan pendapat Aidemark (2001) serta Greatbanks dan Tapp (2007) bahwa sifat multidimensi BSC yang mampu mengukur kinerja organisasi dari aspek non finansial dan menghasilkan KPI yang berfokus pada pencapaian strategi organisasi adalah keunggulan terbesar yang BSC tawarkan untuk diterapkan pada organisasi sektor publik (Chow, Ganulin, Haddad, \& Williamson, 1998; Modell, 2004). Namun, tidak sedikit pihak yang menyangsikan akan keandalan BSC apabila BSC diimplementasikan pada organisasi sektor publik, mengingat organisasi sektor publik memilik proses bisnis yang kompleks (Arnaboldi \& Lapsley, 2004; Arnaboldi, Lapsley, \& Steccolini, 2015; Pidd, 2005). Griffiths (2003) pun memperkuat proposisi tersebut dengan menyatakan bahwa modifikasi kerangka konseptual dengan menempatkan perspektif pelanggan pada bagian atas hierarki dapat merusak nilai tambah BSC sebagai alat pengelolaan kinerja yang efektif.

Namun, belum banyak yang meneliti lebih lanjut tentang alasan keberhasilan atau kegagalan implementasi BSC pada organisasi sektor publik. Beberapa penelitian telah mengidentifikasi faktorfaktor penentu kesuksesan implementasi BSC pada organisasi sektor publik: Chan (2004), KwokwahYeung dan Connell (2006), serta Radnor dan Lovell (2003). Faktor-faktor penentu kesuksesan tersebut meliputi: komitmen manajemen puncak; penerimaan pegawai yang selektif, pelatihan yang memadai, strategi dan tujuan organisasi yang jelas, dan skema insentif yang terhubung dengan sistem manajemen kinerja. Adapun beberapa faktor penghambat dari implementasi BSC adalah sistem informasi yang tidak memadai, tidak ada dukungan dari manajemen puncak, hubungan yang buruk antara atasa dan bawahan, kekurangtajaman desain $\mathrm{KPI}$, dan resistensi yang tinggi dari para pegawainya terhadap sistem baru (Chan, 2004; Kwokwah-Yeung \& Connell, 2006; Radnor \& Lovell, 2003). Namun, faktor-faktor tersebut hanya berhubungan dengan implementasi BSC di sektor swasta. Belum ada penelitian lanjutan yang menganalisis apa faktor kunci sukses dan penghambat implementasi BSC di sektor publik. Perlu juga telah dicatat bahwa terdapat sejumlah tantangan dalam melakukan implementasi BSC pada organisasi sektor publik, seperti perlunya perbaikan atas sistem informasi yang kurang memadai, dan perlunya penanganan terhadap masalah pendefinisian perspektif pelanggan dan apa yang menjadi kebutuhan pelanggan (McAdam \& Walker, 2003; Wisniewski \& Ólafsson, 2004).

\subsection{Best Practices: Perencanaan Strategis dan Pengukuran Kinerja pada Institusi Riset- Pendidikan}

Salah satu kunci sukses dalam penerapan BSC pada organisasi sektor publik, khususnya institusi riset dan pendidikan, adalah ketepatan dalam perancangan rencana strategis organisasi dan pengukuran kinerja organisasi. Yuksel dan Coskun (2013) menjelaskan bahwa perubahan yang cepat di dunia teknologi saat ini telah memaksa organisasi untuk beradaptasi mengikuti perkembangan zaman. Mereka menambahkan bahwa perencanaan strategis yang matang adalah kunci sukses untuk meraih kinerja yang superior dibandingkan kompetitor. Oleh karenanya, pimpinan organisasi riset harus merumuskan strategi administratif dan manajerial yang mumpuni untuk mewujudkan tujuan organisasi (Yüksel \& Coşkun, 2013). Bryson (2004) memberikan gambaran sederhana tentang proses perencanaan strategis yang baik bagi institusi riset-pendidikan (Gambar 2) dengan mendefinisikan $A B C$ terkait perencanaan strategis. $A$ adalah di mana organisasi saat ini berada, $B$ adalah di mana organisasi ingin berada, dan $C$ adalah cara organisasi bisa sampai di sana (Bryson, 2004; Bryson et al., 2009). Visi, misi, dan tujuan organisasi membantu organisasi bergerak dari $A$ ke $B$, formulasi strategi menjembatani agar organisasi bisa bergerak mulus dari A ke C, dan implementasi strategi mendorong agar organisasi bergerak dari B ke C (Bryson, 2004, 2010).

Singkatnya, perencanaan strategis merupakan petunjuk jalan yang akan diambil oleh manajemen untuk mencapai visi dan misi institusi risetpendidikan. Tindakan strategis akan memandu manajemen untuk mencapai tujuan institusi tersebut dengan memberikan arahan strategis tepat, mengalokasikan sumber daya, membangun nilai-nilai organisasi secara simultan, dan menunjukkan keberhasilan atau kegagalan institusi dalam mencapai tujuannya (Yüksel \& Coşkun, 2013). Adapun, manajemen kinerja merupakan suatu sarana untuk mengaudit dan mengelola keseluruhan kegiatan institusi. Hasil pengukuran kinerja suatu kegiatan digunakan untuk menentukan sejauh mana posisi institusi dalam mencapai tujuannya. Pengukuran kinerja bukan hanya proses pengumpulan data semata, melainkan proses untuk meningkatkan efektivitas dan efisiensi dari kegiatan yang dilakukan oleh institusi (Yüksel \& Coşkun, 2013). Oleh karenanya, indikator kinerja institusi harus dipilih dengan cermat. Markless dan Streatfield (2001) menjelaskan lebih lanjut bahwa indikator kinerja yang baik harus memenuhi 8 kriteria, yaitu (1) relevan dengan sasaran organisasi yang diterima, (2) informatif, (3) mampu diubah, (4) andal, (5) dapat diakses, (6) dapat diterima, (7) tidak rusak, dan (8) hemat biaya. 


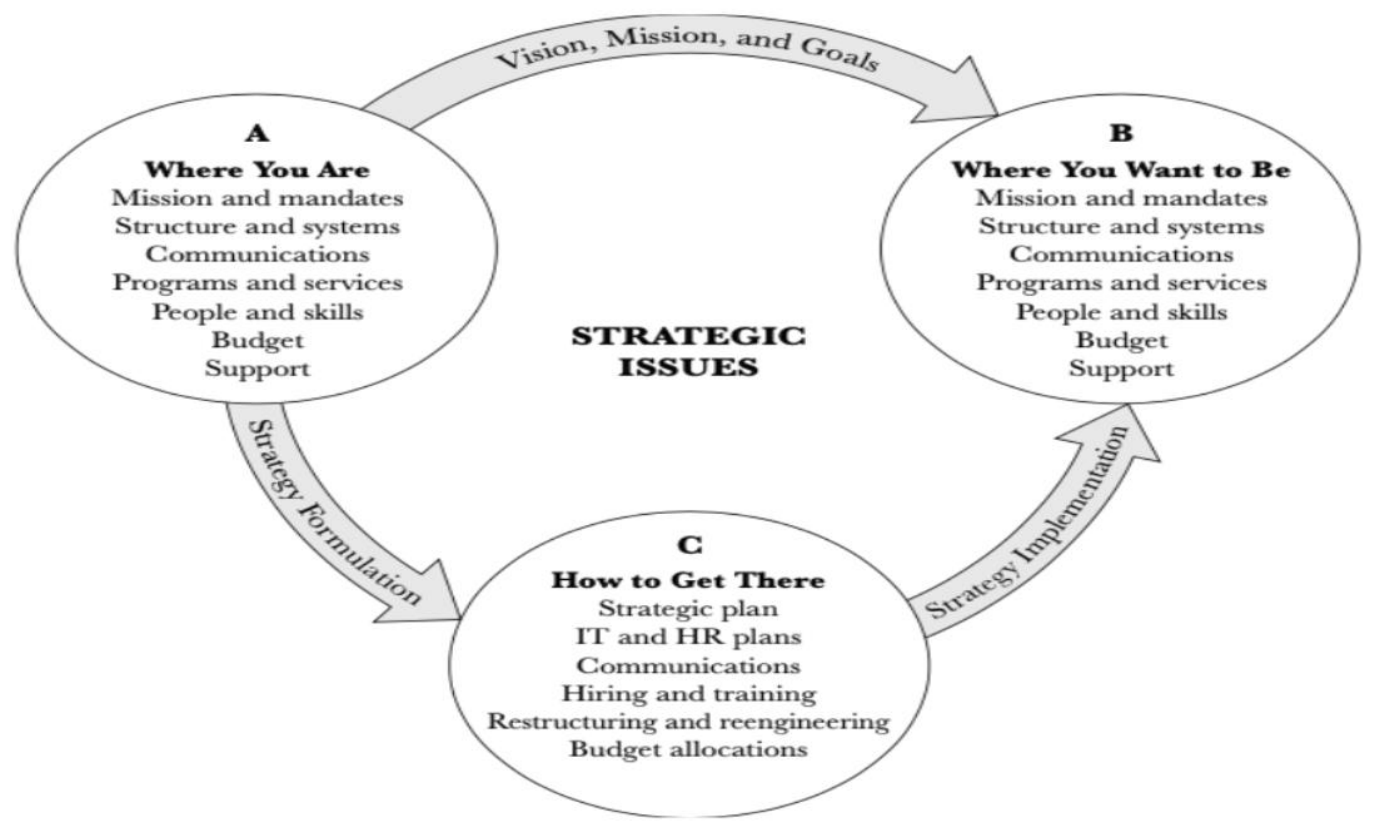

Gambar 2. Alur Perencanaan Strategis (Bryson, 2004)

Sistem pengukuran kinerja pada institusi risetpendidikan dapat didasarkan pada kinerja keuangan atau kinerja non finansial. Analisis laporan keuangan, standar biaya masukan, dan analisis kebutuhan anggaran merupakan contoh pengukuran kinerja keuangan (Yüksel \& Coşkun, 2013). Manajemen institusi tersebut juga dapat menerapkan pendekatan non finansial untuk pengukuran kinerja institusi, seperti kualitas layanan dan kepuasan pelanggan. Kedua pendekatan dalam pengukuran kinerja tersebut terkumpul jadi satu dalam BSC. Bahkan, BSC menyediakan serangkaian alat ukur kinerja keuangan dan kinerja non finansial yang lebih komprehensif bagi institusi sektor publik (Niven, 2006). Meskipun ada banyak alat yang dikembangkan untuk melakukan pengukuran kinerja suatu organisasi, BSC tetap saja memiliki keunggulan tersendiri. BSC menempatkan visi, misi, dan strategi organisasi ke dalam kerangka kerja yang lebih efektif serta mengkomunikasikan tujuan strategis organisasi dengan lebih efisien (Yüksel \& Coşkun, 2013).

\section{METODE PENELITIAN}

\subsection{Pendekatan Penelitian}

Penelitian ini bertujuan untuk mendesain model konseptual BSC sebagai instrumen pengukur kinerja lembaga riset pemerintah, LIPI, kemudian, menggali informasi yang dibutuhkan untuk mengidentifikasi tentang faktor-faktor yang menentukan keberhasilan implementasi BSC pada organisasi sektor publik serta tantangan yang akan dihadapi selama proses implementasi tersebut. Karakteristik dari fenomena yang terjadi menentukan arah dari tujuan penelitian yang hendak dicapai. Oleh karenanya, sifat dari penelitian ini berfokus pada elaborasi untuk mencari solusi atas permasalahan yang terjadi. Sehingga, pertanyaan penelitian ini bersifat penggalian informasi dengan melemparkan pertanyaan semisal "bagaimana, seperti apa, atau mengapa".

Berdasarkan karakteristik fenomena, sifat penelitian, dan tipe pertanyaan penelitian, maka pendekatan penelitian yang tepat untuk mencapai tujuan penelitian ini adalah pendekatan penelitian kualitatif (Creswell, 2014; Miles, Huberman, \& Saldaña, 2014). Metodologi yang digunakan dalam penelitian ini mengaplikasikan metodologi riset kualitatif studi kasus yang dikembangkan oleh (Yin, 2009, 2018). Flick (2007, 2019) serta Denzin dan Lincoln (2017) berpendapat bahwa metodologi riset kualitatif studi kasus memungkinkan peneliti untuk mengeksplorasi lebih dalam tentang seluk-beluk fenomena yang kompleks, khususnya untuk memperoleh perspektif dari pegawai internal organisasi. Selain itu, metodologi ini bersifat fleksibel karena memungkinkan penggunaan berbagai metode penelitian dan dapat digunakan untuk berbagai tujuan yang lebih luas (Yin, 2014).

\subsection{Prosedur Penelitian}

Yin (2018) menjelaskan bahwa penelitian yang menggunakan kerangka konseptual studi kasus harus mengikuti beberapa prosedur, yaitu (1) perumusan pertanyaan studi kasus; (2) penetapan proposi penelitian (jika ada); (3) uraian singkat objek studi yang akan diteliti; (4) penjelasan tentang cara menghubungkan antara data dengan proposisi atau pertanyaan penelitian; serta (5) penjelasan tentang kriteria untuk menginterpretasikan temuan penelitian.

Prosedur pertama bagi peneliti yang hendak menggunakan kerangka konseptual studi kasus adalah menentukan karakteristik pertanyaan penelitian yang tepat. Pertanyaan penelitian harus menggunakan kata tanya: "seperti apa," "bagaimana," atau "mengapa" yang berkaitan dengan serangkaian peristiwa kontemporer di mana peneliti memiliki sedikit control atas peristiwa 
tersebut (Yin, 2018). Sebagaimana telah diuraikan sebelumnya dalam Bab Pendahuluan, pertanyaan utama dari penelitian ini diawali dengan kalimat tanya: "seperti apa desain model konseptual balanced scorecard sebagai alat ukur kinerja bagi LIPI?"

Prosedur kedua adalah merumuskan proposisi penelitian. Penelitian ini tidak menggunakan ataupun menghasilkan suatu proposisi karena sifat dari penelitian ini adalah eksplanatoris yang tidak memerlukan adanya proposisi. Untuk menjawab permasalahan yang terjadi, penelitian ini berusaha mengeksplorasi lebih dalam tentang cara pengembangan kerangka konseptual BSC agar cocok diimplementasikan pada organisasi sektor publik, khususnya pemerintah, dalam mengukur kinerjanya. Kinerja yang akan diukur melalui BSC ke depannya adalah kinerja dari lembaga riset pemerintah, yaitu LIPI.

Prosedur ketiga adalah uraian singkat objek studi yang akan diteliti. Objek studi penelitian ini adalah LIPI sebagai suatu lembaga riset pemerintah. Mengapa harus LIPI? karena penelitian ini akan menghasilkan suatu model konseptual pengukuran kinerja organisasi berbasis BSC yang dapat digunakan oleh LIPI. Peneliti telah melakukan pencarian fakta pada objek studi, di mana peneliti kedua bekerja pada salah satu satuan kerja di LIPI. $\mathrm{Hal}$ ini memudahkan untuk mengumpulkan dokumen internal yang dibutuhkan dalam penelitian ini. Tujuan dari pencarian fakta adalah untuk memperoleh informasi umum tentang visi, misi, kewenangan, dan kegiatan kerja yang LIPI jalankan. Uraian singkat mengenai objek studi diuraikan lebih detail pada Bab Pembahasan.

Selanjutnya, untuk menjawab pertanyaan penelitian terkait kasus pengukuran kinerja berbasis BSC pada LIPI, data yang mesti dikumpulkan adalah data internal LIPI terkait rencana strategis, laporan kinerja, laporan tahunan, dan realisasi capaian kinerja. Selain itu, studi literatur dilakukan terhadap beberapa penelitian terdahulu tentang konsep awal BSC (Kaplan \& Norton, 1992, 1993), konsep BSC sektor publik (Niven, 2008), konsep BSC pada institusi riset-pendidikan (Yüksel \& Coşkun, 2013), serta puluhan literatur lainnya yang relevan dengan topik BSC. Studi literatur ini penting dilakukan untuk memperkuat pemahaman tentang BSC, khususnya bentuk implementasi BSC pada organisasi sektor publik, terutama lembaga riset milik pemerintah agar proses analisis terhadap data yang telah dikumpulkan benar-benar dapat menjawab semua pertanyaan penelitian. Selain itu, studi literatur tambahan dilakukan untuk mengidentifikasi faktorfaktor yang memfasilitasi dan menghambat implementasi BSC pada organisasi sektor publik.

Prosedur keempat, yaitu cara untuk menghubungkan data temuan penelitian dengan pertanyaan penelitian. Cara yang digunakan dalam penelitian ini adalah dengan menggunakan teknik explanation building. Yin $(2009,2018)$ menjelaskan bahwa explanation building merupakan teknik analisis data yang digunakan dalam metodologi riset studi kasus yang bersifat eksplanatoris dengan membangun suatu penjelasan detail tentang kasus yang sedang diteliti. Tujuan dari explanation building adalah untuk mengembangkan suatu ide baru (Yin, 2014).

Dalam konteks penelitian ini, ide baru dimaksud adalah model balanced scorecard pada lembaga riset pemerintah yang mengabstraksi konsep pemikiran para peneliti BSC sebelumnya. Ide baru tersebut kemudian dibingkai dengan penjelasan komprehensif tentang cara perancangan model pengukuran kinerja berbasis balanced scorecard pada LIPI beserta alasan penempatan setiap sasaran strategis LIPI beserta indikator kinerjanya pada masing-masing perspektif BSC. Untuk membangun suatu eksplanasi yang komprehensif, dilakukan beberapa tahapan, yaitu pertama, menyusun rancangan awal model BSC LIPI; kedua, melakukan perbandingan antara model awal tersebut dengan hasil studi literatur; ketiga, melakukan revisi atas model awal tersebut untuk dicocokkan kembali dengan karakteristik proses bisnis LIPI; keempat, melakukan proses pada tahap ketiga secara iteratif untuk menghasilkan model akhir pengukuran kinerja berbasis BSC pada LIPI.

Prosedur terakhir yang harus dilaksanakan dalam implementasi kerangka konseptual riset studi kasus adalah prosedur untuk menginterpretasikan temuan penelitian, yaitu analytic generalization. Yin (2018) menjelaskan bahwa analytic generalization merupakan proses generalisasi hasil temuan terhadap kerangka teori yang digunakan. Caranya adalah dengan menjelaskan implikasi hasil temuan tersebut terhadap kerangka teori, apakah mendukung atau menolak konsep pemikiran yang terkandung dalam teori yang digunakan (Yin, 2018). Untuk mencapai tingkatan analytic generalization, peneliti mengabstraksi hasil pengembangan desain BSC untuk lembaga riset pemerintah terhadap kerangka teori BSC untuk organisasi sektor publik dan kerangka teori BSC sebagai alat ukur kinerja institusi riset dan pendidikan.

Tiga prosedur awal dari metodologi riset studi kasus, yaitu (1) mendefinisikan pertanyaan penelitian, (2) merumuskan proposisi penelitian, dan (3) mendeskripsikan objek studi berguna untuk mempertajam metode pengumpulan data dalam suatu penelitian studi kasus (Yin, 2018). Dua prosedur terakhir, yaitu (4) mendefinisikan cara yang digunakan untuk menghubungkan data dengan pertanyaan penelitian, serta (5) teknik untuk menafsirkan temuan penelitian akan mempertajam hasil analisis temuan dan memperjelas langkah yang harus dilakukan setelah data dikumpulkan (Yin, 2018).

\section{HASIL PENELITIAN}

\subsection{LIPI: Hegemoni Sebuah Institusi Riset- Pendidikan Nasional}

Lembaga penelitian pertama, terbesar dan terbaik di Indonesia. Pembentukan LIPI memiliki 
sejarah yang panjang. Setelah melewati beberapa fase kegiatan ilmiah sejak abad ke-16 hingga tahun 1956, pemerintah Indonesia membentuk Majelis Ilmu Pengetahuan Indonesia (MIPI) melalui UndangUndang (UU) Nomor 6 Tahun 1956. Tugasnya adalah membimbing perkembangan ilmu pengetahuan dan teknologi serta memberi pertimbangan kepada pemerintah dalam hal kebijaksanaan ilmu pengetahuan. Pada tahun 1962, pemerintah membentuk Departemen Urusan Riset Nasional (DURENAS) dan menempatkan MIPI di dalamnya dengan tugas tambahan membangun dan mengasuh beberapa lembaga riset nasional. Hingga pada tahun 1966, status DURENAS ditingkatkan menjadi Lembaga Riset Nasional (LEMRENAS). Sejak Agustus 1967, pemerintah membubarkan LEMRENAS dan MIPI dengan Keputusan Presiden Republik Indonesia (Keppres) Nomor 128 Tahun 1967. Setelah itu, pemerintah, berdasarkan Keputusan Majelis Permusyawaratan Rakyat Sementara Nomor: 18/B/1967, membentuk LIPI dan menampung seluruh tugas LEMRENAS dan MIPI ke dalam lembaga tersebut.

Tugas pokok LIPI adalah (1) membimbing perkembangan ilmu pengetahuan dan teknologi yang berakar di Indonesia agar dapat dimanfaatkan bagi kesejahteraan rakyat Indonesia pada khususnya dan umat manusia pada umumnya; (2) mencari kebenaran ilmiah di mana kebebasan ilmiah, kebebasan penelitian serta kebebasan mimbar diakui dan dijamin, sepanjang tidak bertentangan dengan Pancasila dan Undang-Undang Dasar 1945; (3) mempersiapkan pembentukan Akademi Ilmu Pengetahuan Indonesia (sejak 1991, tugas pokok ini selanjutnya ditangani oleh Menteri Negara Riset dan Teknologi melalui Keppres Nomor 179 tahun 1991). Seiring perkembangan kemampuan nasional dalam bidang ilmu pengetahuan dan teknologi, lembaga ilmiah di Indonesia pun mengalami pertumbuhan dan perkembangan. Menyikapi hal tersebut, peninjauan dan penyesuaian tugas pokok dan fungsi serta susunan organisasi LIPI terus dilakukan. Di antaranya adalah penetapan Keppres Nomor 128 Tahun 1967 yang diubah terakhir dengan dengan Keppres Nomor 43 Tahun 1985. Keppres tersebut masih disempurnakan lebih lanjut melalui Keppres Nomor 1 Tahun 1986 tentang Lembaga IImu Pengetahuan Indonesia. Terakhir, penyempurnaan dilakukan melalui penetapan Keppres Nomor 103 Tahun 2001.

Visi LIPI adalah menjadi lembaga ilmu pengetahuan berkelas dunia dalam penelitian, pengembangan dan pemanfaatan ilmu pengetahuan untuk meningkatkan daya saing bangsa. Misinya adalah (1) menciptakan invensi ilmu pengetahuan yang dapat mendorong inovasi dalam rangka meningkatkan daya saing ekonomi bangsa; (2) mengembangkan ilmu pengetahuan yang bermanfaat untuk konservasi dan pemanfaatan Sumber Daya berkelanjutan; (3) meningkatkan pengakuan internasional dalam bidang ilmu pengetahuan; dan (4) meningkatkan kualitas SDM Indonesia melalui aktivitas IImiah.
Adapun tujuan LIPI adalah (1) peningkatan temuan, terobosan dan pembaharuan ilmu pengetahuan serta pemanfaatannya dalam mewujudkan daya saing bangsa; (2) peningkatan nilai tambah dan kelestarian Sumber Daya Indonesia; (3) peningkatan posisi dan citra Indonesia di komunitas global dalam bidang ilmu pengetahuan; (4) peningkatan budaya ilmiah masyarakat Indonesia.

Setelah visi, misi, dan tujuan LIPI ditetapkan. Kemudian, dirumuskan terkait Fungsi LIPI, yaitu (1) pengkajian dan penyusunan kebijakan nasional di bidang penelitian ilmu pengetahuan; (2) penyelenggaraan riset keilmuan yang bersifat dasar; (3) penyelenggaraan riset inter dan multi disiplin terfokus; (4) pemantauan, evaluasi kemajuan, dan penelaahan kecenderungan iptek; (5) koordinasi kegiatan fungsional dalam pelaksanaan tugas LIPI; (6) fasilitasi dan pembinaan terhadap kegiatan instansi pemerintah di bidang penelitian ilmu pengetahuan; (7) penyelenggaraan pembinaan dan pelayanan administrasi umum.

Untuk mencapai visi, misi, dan tujuan tersebut, LIPI melakukan beberapa tugas inti sesuai dengan fungsinya, yaitu: (1) program penelitian, penguasaan, dan pemanfaatan ilmu pengetahuan dan teknologi (Iptek) yang berdampak besar, signifikan dan nyata (BSN), seperti: penelitian ilmu pengetahuan hayati termasuk pengembangan pangan dan obat serta bioresources;(2) Pengukuran dan penelitian perkembangan Iptek yang bertujuan untuk meningkatkan kapasitas penelitian kebijakan iptek dan manajemen riset teknologi, serta pengembangan indikator ilmu pengetahuan dan teknologi; (3) Penerapan hasil penelitian untuk peningkatan ekonomi masyarakat; (4) Sosialisasi dan diseminasi hasil-hasil penelitian LIPI sebagai upaya mencerdaskan bangsa dan meningkatkan kesejahteraan masyarakat; (5) Pembinaan, pengembangan, pendidikan dan pelatihan peneliti nasional melalui peningkatan mutu pembinaan dan diklat serta peningkatan kualitas peneliti melalui sertifikasi, kode etik peneliti dan penganugerahan profesor riset; (6) Penguatan jaringan kelembagaan ilmu pengetahuan dan teknologi melalui terbangunnya kerja sama antar lembaga penelitian dan pengembangan, perguruan tinggi, dan industri/masyarakat pengguna; (7) Pembinaan ilmiah masyarakat (kelompok ilmiah remaja, mahasiswa, guru dan organisasi profesi) seperti Lomba Karya IImiah Remaja (LKIR), Perkemahan IImiah Remaja Nasional, LIPI Young Scientist Award dan National Young Inventor Award.

Dalam menjalankan tugas inti tersebut, LIPI diberikan kewenangan yang sangat besar oleh pemerintah. Kewenangan tersebut, antara lain, yaitu (1) LIPI merupakan institusi pemegang otoritas keilmuan dalam berbagai aspek, seperti pemberian data dan timbangan ilmiah dalam rangka konservasi keanekaragaman hayati, termasuk juga dalam pelaksanaan konvensi internasional, seperti Convention on International Trade in Endangered Species of Wild Fauna (CITES) dan Convention on 
Biological Diversity (CBD). (2) Berdasarkan Peraturan Pemerintah (PP) Nomor 7 Tahun 1999 tentang Pengawetan Jenis Tumbuhan dan Satwa, PP No. 8/1999 tentang Pemanfaatan Jenis Tumbuhan dan Satwa Liar, serta PP Nomor 60 Tahun 2007 tentang Konservasi Sumber Daya Ikan, LIPI ditetapkan sebagai otoritas keilmuan dengan wewenang antara lain: memberikan rekomendasi kepada otoritas pengelola tentang penetapan daftar klasifikasi, kuota penangkapan dan perdagangan, termasuk ekspor, reekspor, impor, introduksi dari laut semua spesimen tumbuhan dan satwa. (3) LIPI berperan dalam memberikan data dan timbangan ilmiah dalam Rencana Tata Ruang dan Wilayah (RTRW) serta dalam penetapan kawasan konservasi in-situ dengan menggunakan konsep Cagar Biosfer sebagai Model Pengelolaan Kawasan untuk Pembangunan Berkelanjutan di Indonesia. (4) Berdasarkan Perpres Nomor 93 Tahun 2011 tentang Kebun Raya, LIPI diberikan mandat untuk menetapkan rencana pengembangan Kebun Raya di Indonesia serta memberikan pendampingan, pembinaan, dan pengawasan teknis perkebunrayaan. (5) Sesuai dengan Keppres Nomor 13 Tahun 1997 tentang Badan Standardisasi Nasional dan Keppres Nomor 79 Tahun 2001 tentang Komite Standar Nasional Satuan Ukuran (KSNSU), LIPI mendapat amanat untuk mendukung pelaksanaan tugas dan fungsi KSNSU sebagai pengelola teknis ilmiah standar nasional untuk satuan ukuran. (6) Berdasarkan Peraturan Menteri PAN-RB Nomor KEP/128/M.PAN/2004 tentang jabatan fungsional peneliti dan angka kreditnya, LIPI memiliki kewenangan sebagai pembina jabatan fungsional peneliti nasional dan bertanggung jawab menilai akreditasi peneliti dan mengawasi kualitas termasuk etika peneliti, baik peneliti LIPI maupun kementerian dan lembaga lain non LIPI. (7) LIPI berwenang untuk membina dan melaksanakan proses pengukuhan profesor riset untuk seluruh peneliti dari institusi riset di Indonesia. (8) LIPI merupakan National Center of International Standard Serial Number dengan kewenangan untuk menerbitkan International Standard Serial Number (ISSN) dan melakukan pemantauan atas seluruh publikasi terbitan berkala yang diterbitkan di Indonesia. (9) LIPI memiliki hak untuk mengelola National Science and Technology Park di Cibinong Science Center dan 7 Techno Park di Samosir, Sumatera Utara; Tasikmalaya, Jawa Barat; Banyumulek, Nusa Tenggara Barat; Enrekang, Sulawesi Selatan; Mataram; Ternate, Maluku Utara; dan Tual Maluku. (10) Di tingkat internasional, LIPI menjadi anggota berbagai lembaga ilmiah internasional dan berperan sebagai focal point nasional untuk: Association of Asian Social Science Research Councils (AASSREC); Asia Pacific Metrology Program (APMP); Asia and Pacific Centre for Transfer Technology (APCTT); Flora Malesiana Foundation (Rijksherbarium); International Council of Sciencetific Union (ICSU); Committee on Data for Science and Technology (CODATA-ICSU); International Federation of Social Science Organizations (IFSSO); Pacific
Science Association (PSA); World Association of Industrial and Technological Research Organizations (WAITRO); Botanic Gardens Conservation International (BGCl); Global Biodiversity Information Facility (GBIF).

\subsection{Balanced Scorecard Lembaga Riset Pemerintah: Mempertajam Kinerja LIPI}

Model kerangka koseptual BSC untuk organisasi sektor publik berbeda dengan model kerangka konseptual BSC awal yang memang didesain khusus organisasi sektor swasta (Niven, 2006). Perbedaan tersebut terletak pada penempatan misi organisasi di posisi teratas dalam kerangka BSC. Posisi ini menunjukkan bahwa misi menjadi tujuan utama organisasi dengan perspektif pelanggan sebagai pendorongnya, karena organisasi sektor publik lebih berfokus pada pelayanan masyarakat. Menurut Niven (2008), organisasi sektor publik yang menggunakan BSC dapat memodifikasi persperktif yang digunakan baik dari segi jumlah maupun jenis. Modifikasi ini dilakukan sesuai dengan kebutuhan organisasi dalam merefleksikan strateginya secara lebih baik. Pada umumnya, organisasi sektor publik dapat membagi perspektif pelanggan menjadi 2 (dua) bagian, yakni perspektif pelanggan dan perspektif pemangku kepentingan. Hal ini diperlukan mengingat banyaknya jenis pelanggan yang dimiliki oleh organisasi sektor publik sebagai organisasi yang berorientasi pada pelanggan. Sehingga, organisasi sektor publik memerlukan pengklasifikasian yang lebih spesifik untuk memudahkan dalam menentukan sasaran strategis dan ukuran yang tepat. Selain itu, Niven (2006) menyarankan bahwa perspektif keuangan tetap harus digunakan karena sifat dari perspektif keuangan adalah sebagai pendorong keberhasilan layanan terhadap pelanggan.

Bagi organisasi sektor publik, pengukuran kinerja tidak hanya sebatas penetapan indikator kinerja semata, melainkan mencakup juga penilaian kinerja. Setelah itu, barulah dilakukan analisis kinerja dengan menginterpretasikan lebih lanjut hasil penilaian kinerja tersebut untuk menggambarkan keberhasilan atau kegagalan suatu instansi pemerintah dalam melaksanakan misi dan mencapai tujuannya. Untuk mengimplementasikan kerangka pengukuran kinerja ala balanced scorecard ke dalam organisasi sektor publik, penentuan indikator kinerja harus sesuai dengan sistem informasi manajemen secara keseluruhan pada orgakutaanisasi tersebut (Niven, 2008; Radnor \& Lovell, 2003). Lebih lanjut, Jones dan Pendlebury (2010) mengemukakan bahwa pengukuran kinerja dari suatu organisasi sektor publik dilakukan untuk memenuhi tiga tujuan sebagai berikut: (1) untuk membantu memperbaiki kinerja pemerintah agar pemerintah dapat berfokus pada tujuan dan sasaran program unit kerja. Hal ini, pada akhirnya, akan meningkatkan efektivitas dan efisiensi organisasi sektor publik dalam memberikan pelayanan publik. (2) Untuk pengalokasian sumber 
daya dan pembuatan keputusan. (3) Untuk mewujudkan pertanggungjawaban publik dan memperbaiki komunikasi kelembagaan.

Selain ketiga tujuan tersebut, Jones dan Pendlebury (2010) menjelaskan lebih lanjut bahwa pengukuran kinerja bagi sektor publik juga bermanfaat untuk (1) memberikan pemahaman mengenai ukuran yang digunakan untuk menilai kinerja manajemen, (2) memberikan arah untuk mencapai target kinerja yang telah ditetapkan, (3) untuk memonitor, mengevaluasi pencapaian kinerja dan membandingkannya dengan target kinerja serta melakukan tindakan korektif memperbaiki kinerja, (4) sebagai dasar untuk memberikan penghargaan dan hukuman secara obyektif atas pencapaian prestasi yang diukur sesuai dengan sistem pengukuran kinerja yang telah disepakati, (5) sebagai alat komunikasi antara bawahan dan pimpinan dalam rangka memperbaiki kinerja organisasi, (6) membantu mengidentifikasi apakah kepuasan pelanggan sudah terpenuhi, (7) membantu memahami proses kegiatan instansi pemerintah, serta (8) memastikan pengambilan keputusan dilakukan secara obyektif.

Berdasarkan penjelasan dari Niven (2006) serta Jones dan Pendlebury (2010), desain model BSC bagi LIPI harus diawali dengan proses identifikasi sasaran strategis dan indikator kinerja utama (IKU) LIPI yang dipetakan berdasarkan 4 perspektif BSC. Sasaran dan indikator tersebut dapat dilihat dalam Keputusan Kepala Lembaga Ilmu Pengetahuan Indonesia Nomor 11/M/2017 tentang Indikator Kinerja Utama Lembaga IImu Pengetahuan Indonesia Tahun 20172019 (Gambar 3). Sepanjang tahun 2017, LIPI selalu mencapai bahkan melebihi dari target IKU yang dicanangkan (Tabel 1). Untuk melihat sampai sejauh mana dampak dari pencapaian target tersebut terhadap berbagai tujuan dan pemangku kepentingan, maka target capaian, IKU, dan sasaran strategis LIPI harus dipetakan ke dalam kerangka konseptual BSC (Yüksel \& Coşkun, 2013) dengan menempatkan perspektif pemangku kepentingan pada posisi atas hierarki (Niven, 2008), kemudian diikuti dengan perspektif proses bisnis internal, perspektif inovasi dan pembelajaran, serta perspektif keuangan. Perspektif keuangan harus tetap ada mengingat keberadaan perspektif keuangan akan mendorong keberhasilan layanan terhadap para pemangku kepentingan, terutama masyarakat sebagai pemangku kepentingan utama (Niven, 2006).

Perspektif keuangan tersebut dimodifikasi lebih lanjut oleh Yüksel dan Coşkun (2013) menjadi perspektif keuangan yang berkelanjutan. Hierarkinya pun berubah menjadi perspektif: pemangku kepentingan, proses bisnis internal, inovasi dan pembelajaran, serta keuangan berkelanjutan. Hal ini menunjukkan bahwa organisasi sektor publik harus mampu menjaga amanah dari pemberi modal utama, yaitu masyarakat, dengan menggunakan public money tersebut secara bertanggung jawab sehingga keberadaan organisasi akan terus berlanjut dalam jangka panjang (Yüksel \& Coşkun, 2013). Oleh karenanya, model balanced scorecard yang cocok untuk digunakan dalam menilai kinerja dari proses bisnis yang dijalankan oleh LIPI adalah model BSC Yüksel dan Coşkun (2013). Mereka menyatakan bahwa tujuan utama dari penggunaan BSC adalah untuk menjamin keberlangsungan pembangunan sosial ekonomi jangka panjang. Untuk mencapai tujuan tersebut, perlu ditunjang oleh perspektif lain berupa, perpektif keuangan berkelanjutan, perspektif inovasi dan pembelajaran, perspektif proses bisnis internal, serta perspektif pemangku kepentingan.

\section{INDIKATOR KINERJA UTAMA LEMBAGA ILMU PENGETAHUAN INDONESLA TAHUN 2017-2019 \\ 1. Kementerian/Lembaga 2. Tugas Fungai \\ Lembaga Ilmu Pengetahusn Indoneria (LIPI) Melalcsanalcan tugas pemerintahan di bidsng penelitian ilmu pengetahuan seruai dengan lcetentuan peraturan perundang-undangan 3. Penanggung jawab Kepala LIPI}

\begin{tabular}{|c|c|}
\hline Sacaran Strategic & Indilcator Kinerja Utama (IKU) \\
\hline $\begin{array}{l}\text { Meningleatnya lcontribusi LIPI } \\
\text { terhadap daya saing bangsa } \\
\text { berbasis hasil penelitian. }\end{array}$ & $\begin{array}{l}\text { 1. Jumlah sitasi atas publilcaci L.JPI. } \\
\text { 2. Jumlah hasil penelitian dan HKI } \\
\text { yang dimanfastlcan. } \\
\text { 3. Jumlah STP/TP yang } \\
\text { termanfaatlcan. } \\
\text { 4. Jumlah pengeuna jaca LIPI. } \\
\text { 5. Jumlah policy paper/relcomendasi } \\
\text { lcebijalcan/lceputusan yang } \\
\text { dimanfaatlcan. } \\
\text { 6. Peringlcat LIPI di Webometric. }\end{array}$ \\
\hline $\begin{array}{l}\text { Terwujudnya tatalcelola } \\
\text { pemerintahan yang bailk. }\end{array}$ & $\begin{array}{l}\text { 1. Peningleatan jumlah peneliti } \\
\text { nacional. } \\
\text { 2. Nilai Reformasi Birolerasi }\end{array}$ \\
\hline
\end{tabular}


1. Meningkatnya kontribusi LIPI terhadap daya saing bangsa berbasis hasil penelitian
1. Jumlah sitasi atas Publikasi
2. Jumlah hasil penelitian dan HKI yang dimanfaatkan

\section{Sitasi}

Buah

142.500

145

169.316

209

119
Jumlah STP/TP
termanfaatkan

4. Jumlah pengguna jasa LIPI
5. Jumlah policy paper/ rekomendasi kebijakan/ keputusan yang dimanfaatkan

6. Peringkat LIPI di Webometrics

2. Terwujudnya tata kelola pemerintahan yang baik

7. Peningkatan Jumlah Peneliti Nasional

8. Nilai Reformasi Birokrasi yang

Peringkat

140

593 Orang

Nilai

78

100

Tabel 1. Realisasi Capaian Kinerja LIPI 2017 Sumber: Laporan Kinerja LIPI 2017

\section{Perspektif Keuangan Berkelanjutan}

Perspektif ini ditempatkan pada posisi paling bawah, karena berfungsi sebagai pondasi bagi perspektif yang lain. Pondasi ini merupakan bagian yang terpenting dalam suatu struktur organisasi maka diperlukan perhatian terhadap struktur ini. Menurut Yuksel \& Coskun (2013), indikator yang digunakan untuk menilai keberlanjutan keuangan adalah (1) menilai seberapa efektif strategi produktivitasnya, melaui seberapa besar penghematan anggaran dan utilisasi pemanfaatan aset tetap yang dilakukan; serta (2) menilai seberapa besar strategi pertumbuhan organisasi, melalui seberapa besar peluang ekspansi penerimaan, nilai perusahaan dari sisi pelanggan, dan keberlanjutan fiskal. Bentuk implementasi kerangka konseptual tersebut ke dalam konteks LIPI, yaitu dengan menempatkan sasaran strategis: "terwujudnya manajemen tata kelola pemerintah di LIPI yang baik dan bersih" sebagai perspektif keuangan berkelanjutan. Indikator yang digunakan mengukur kinerja sasaran strategis tersebut adalah "nilai reformasi birokrasi LIPI".

Mengapa sasaran strategis tersebut dikategorikan ke dalam perspektif keuangan berkelanjutan sementara indikator dari sasaran trategisnya adalah nilai reformasi birokrasi? Alasannya adalah untuk melihat perkembangan pelaksanaan reformasi birokrasi, diperlukan instrumen yang tepat dalam menilai secara detail apakah reformasi birokrasi tersebut benar-benar sudah dilakukan dengan baik atau tidak, serta penilaiannya lebih diarahkan pada hasil akhir (outcome), bukan output. Selain itu, pelaksanaan program reformasi birokrasi, pada prinsipnya, dimaksudkan agar terjadi efisiensi dan perbaikan kinerja pada LIPI sebagai suatu lembaga riset pemerintah. Oleh karena itu, perlu dilakukan evaluasi mengenai seberapa besar dampak pelaksanaan reformasi birokrasi di LIPI terhadap perbaikan kinerja dan efisiensi anggaran. ${ }^{1}$ Sehingga, pernyataan tersebut memiliki kesesuaian dengan tujuan utama dari perspektif keuangan berkelanjutan menurut Yüksel dan Coşkun (2013).

Perspektif Inovasi dan Pembelajaran

Perspektif ini merupakan suatu perspektif yang berada pada lapisan ketiga hierarki BSC dan terdiri dari berbagai sumber daya dan nilai yang dimiliki oleh organisasi yang digunakan untuk mencapai tujuan akhirnya (Yüksel \& Coşkun, 2013). Berbagai sumber daya dan nilai tersebut terbagi menjadi: (1) sumber daya manusia, terdiri dari: kepuasan pegawai, berbagai pelatihan yang diikuti oleh pegawai, lingkungan kerja, serta pengetahuan yang dimiliki oleh pegawai; (2) sumber daya organisasi, terdiri dari: budaya organisasi, kerjasama tim, kepemimpinan, serta inovasi; (3) sumber daya fisik, terdiri dari: fasilitas fisik, investasi teknologi, fasilitas olahraga, dan sarana transportasi. Apabila kerangka konseptual tersebut diaplikasikan ke dalam konteks LIPI, maka sasaran strategis yang ditempatkan sebagai perspektif inovasi dan pembelajaran adalah "meningkatnya kontribusi LIPI terhadap daya saing bangsa berbasis hasil penelitian", dan "terwujudnya tata kelola pemerintahan yang baik". Indikator yang digunakan

\footnotetext{
1 Diperoleh dari Laporan Monitoring Reformasi Birokrasi (Pelaksanaan Reformasi Birokrasi Satuan Kerja di LIPI) tahun 
untuk mengukur kinerja keduanya, yaitu "peringkat LIPI di Webometric", dan "peningkatan jumlah peneliti Indonesia". Peringkat Webometrics untuk lembaga penelitian atau yang lebih dikenal sebagai Webometrics, adalah inisiatif dari Lab, sebuah grup penelitian di bawah Consejo Superior de Investigaciones Cient Ãficas (CSIC), lembaga penelitian terbesar di Spanyol.

Metode kuantitatif yang sering digunakan untuk mengukur kinerja lembaga penelitian di seluruh dunia dikembangkan oleh the Cybermetrics $L a b$, yang merupakan bagian dari CSIC. Lab ini berfokus pada analisa kuantitatif berbasis internet dan konten situs khusus yang terkait dengan proses penciptaan dan komunikasi ilmiah dari pengetahuan ilmiah. $^{2}$ Peringkat webometrics ini dikelompokkan ke dalam perspektif inovasi dan pembelajaran karena peringkat webometrics ini merupakan instrument yang tepat untuk mengukur bagaimana kinerja dari lembaga penelitian dengan melihat berbagai sumber daya yang ada, baik itu sumber daya yang tak berwujud, dalam hal ini berupa paten, hak cipta, informasi mengenai LIPI di internet, dan lain sebagainya, maupun sumber daya berupa laboratorium-laboratorium yang tersebar di seluruh Indonesia. Selain itu, indikator kedua yang digunakan untuk mengukur kinerja sasaran strategis terkait, yaitu "meningkatnya jumlah peneliti Indonesia", dimasukkan ke dalam perspektif inovasi dan pembelajaran karena indikator ini akan memperkuat sumber daya manusia yang ada.

\section{Perspektif Proses Bisnis Internal}

Perspektif ini menempati lapisan kedua pada hierarki BSC (Yüksel \& Coşkun, 2013). Perspektif ini memiliki berbagai indikator kinerja seperti penelitian unggulan, partisipasi dalam even nasional, partisipasi dalam kegiatan sosial, prestasi akademis pegawai. Apabila kerangka kosenptual tersebut diterapkan dalam konteks LIPI, maka sasaran strategis yang ditempatkan sebagai perspektif inovasi dan pembelajaran adalah "meningkatnya kontribusi LIPI terhadap daya saing bangsa berbasis hasil penelitian". Indikator yang digunakan untuk mengukur kinerjanya adalah "jumlah policy paper/rekomendasi kebijakan/keputusan yang dimanfaatkan." Sasaran strategis ini dimasukkan ke dalam perspektif ini karena indikator kinerja terkait mencerminkan keberhasilan LIPI dalam memberikan rekomendasi kebijakan berbasis hasil penelitian kepada pemerintah selaku pemangku kepentingan. Sehingga, pemerintah dapat menggunakan hasil penelitian LIPI sebagai dasar pembuatan kebijakan atau keputusan penting. ${ }^{3}$ Selain untuk kepentingan eksternal, hasil dari policy paper/rekomendasi kebijakan/keputusan ini digunakan oleh pihak internal LIPI untuk melakukan perbaikan dalam proses bisnisnya. Contohnya adalah LIPI kini sudah menetapkan standar yang tinggi dalam pelaksanaan penelitian di bidang teknologi nano, sehingga penelitian di bidang tersebut akan membuahkan hasil penelitian yang berkualitas tinggi. Dari contoh tersebut dapat dikatakan bahwa adanya standar dimaksud mencerminkan adanya perbaikan proses bisnis yang LIPI lakukan terkait kegiatan penelitian yang menjadi inti proses bisnis LIPI.

\section{Perspektif Pemangku Kepentingan}

Perspektif ini ditempatkan oleh Yüksel dan Coşkun (2013) pada lapisan teratas dalam hierarki balance scorecard. Indikator yang digunakan untuk mengukur kinerja perspektif ini adalah citra organisasi, kepuasan pelanggan, loyalitas pegawai, layanan yang berkualitas, dan kerja sama dengan organisasi terkemuka lain. Implementasi kerangka konseptual Yüksel dan Coşkun (2013) dalam konteks LIPI adalah menempatkan sasaran strategis: "meningkatnya kontribusi LIPI terhadap daya saing bangsa berbasis hasil penelitian" ke dalam perspektif pemangku kepentingan. Indikator yang digunakan untuk mengukur kinerjanya adalah "jumlah Sitasi atas publikasi LIPI", "jumlah hasil penelitian dan Hak Kekayaan Intelektual (HKI) yang dimanfaatkan", "jumlah Science Tecno Park/Techno Park (STP/TP) yang termanfaatkan", serta "jumlah pengguna jasa LIPI". Sejatinya, LIPI berada di bawah koordinasi Kementerian Riset dan Teknologi. Hal tersebut menjadikan LIPI sebagai lembaga riset resmi pemerintah. Sebagai instansi pemerintah, tentunya LIPI memiliki tugas penting dalam memberikan pelayanan terbaik kepada para pemangku kepentingannya. Kemajuan dan daya saing suatu negara tercermin dari seberapa produktifnya negara tersebut dalam menghasilkan suatu inovasi dan terobosan di bidang riset. Salah satu keluaran riset adalah publikasi ilmiah yang kualitasnya diukur berdasarkan seberapa banyak publikasi ilmiah tersebut disitasi sebagai referensi/pustaka oleh artikel lain. Kualitas publikasi juga dapat dilihat dari Hirsch Index (h-index). Sitasi menjadi ukuran yang tepat untuk melihat kontribusi secara global dan daya saing berbasiskan hasil penelitian. Hal ini mengindikasikan bahwa hasil publikasi dari sivitas LIPI tergolong baik dan mendapat pengakuan dari kalangan masyarakat ilmiah internasional. ${ }^{4}$

Sebagai lembaga penelitian, LIPI diharapkan menghasilkan penelitian yang bermanfaat bagi peningkatan taraf hidup masyarakat, peningkatan ekonomi, maupun peningkatan daya saing suatu bangsa. ${ }^{5}$ Sehingga, hasil penelitian dan kekayaan intelektual LIPI akan banyak dimanfaatkan oleh para pemangku kepentingan LIPI. Contohnya adalah dalam bidang Pangan dan Peternakan, aplikasi IB Sexing 2.000 dosage telah didesiminasikan di Kabupaten Lombok Barat, Kabupaten Lombok Tengah dan Kabupaten Lombok Timur. Sementara aplikasi IB Sperma Sexing Sapi FH 100 dosis dan Sperma Sapi FH 1.500 dosis telah diterapkan di Tapos, Kabupaten Bogor. Selain itu, ada formula

\footnotetext{
2 Diambil dari Laporan Kinerja LIPI 2017

${ }^{3}$ lbid. $\quad{ }^{5}$ Ibid.
} 
starter yang mengandung Lactobacillus Plantarum untuk pembuatan moacaf dan proses Pembuatannya yang telah dimanfaatkan oleh UKM Laris Manis Solok, UKM Kapuah Saiyo Solok, UKM Bareh Solok, Koperasi Wanita Madania Kudus, Pondok Pesantren Al Mawadah Kudus, serta beberapa industri moacaf di Gunung Kidul, Yogyakarta. Dalam bidang energi baru dan terbarukan, temuan peneliti LIPI berupa metode dan alat untuk memasok bahan bakar biogas, khususnya alat yang digunakan untuk mengkondisikan tekanan biogas dan sekaligus memurnikan bahan bakar biogas, telah diimplementasikan dan digunakan oleh Pondok Pesantren Baiturrahman, Ciparay, Kabupaten Bandung. ${ }^{6}$ Di sisi lain, pembangunan Science Techno Park (STP) yang merupakan program nasional diharapkan mampu mendorong peningkatan ekonomi daerah melalui penerapan teknologi yang telah dihasilkan oleh LIPI. ${ }^{7}$ Pada tahun 2017, STP yang dikelola oleh LIPI meliputi Cibinong Science and Techno Park, dan Techno Park Banyumulek.

Jumlah pengguna jasa LIPI pada tahun 2017 melebihi 58,01\% dari target yang dicanangkan, atau sebanyak 72.251 orang. Jumlah ini merupakan jumlah tertinggi selama tiga tahun terakhir: 49.073 orang di tahun 2015 dan 41.877 orang di tahun 2016. Hal ini tercapai berkat usaha bersama seluruh sivitas LIPI dalam mewujudkan layanan publik bagi para pemangku kepentingannya dan juga bertepatan dengan perayaan 50 tahun LIPI. Kondisi ini juga menunjukkan bahwa peran Biro Kerjasama, Hukum, dan Hubungan Masyarakat LIPI bersama-sama dengan Bidang Pengelolaan dan Diseminasi Hasil Penelitian di setiap satuan kerja LIPI semakin aktif dalam melakukan promosi terhadap hasil-hasil penelitian LIPI. Sehingga, hal tersebut mampu menarik minat masyarakat pengguna untuk datang dan menggunakan jasa LIPI. ${ }^{8}$

Dengan demikian, desain BSC untuk mempertajam pengukuran kinerja LIPI dalam mencapai tujuannya terangkum dalam Gambar 4. Pemetaan hasil capaian kinerja yang telah LIPI lakukan berdasarkan 4 perspektif BSC (Yüksel \&
Coşkun, 2013) tergambar dalam Tabel 2. Pada titik ini, dapat disimpulkan bahwa model konseptual BSC yang sejatinya dirancang untuk perusahaan sektor swasta terbukti dapat diimplementasikan pada organisasi sektor publik dengan melakukan sedikit penyesuaian terhadap kerangka konseptualnya. Dalam hal ini, penyesuaian dimaksud dilakukan dengan mengikuti kerangka pemikiran Yüksel dan Coşkun (2013) serta Niven (2006, 2008), yaitu dengan menempatkan perspektif pemangku kepentingan pada posisi tertinggi pada hierarki BSC, sementara perspektif keuangan berkelanjutan difungsikan sebagai pondasi bagi perspektif lain, sehingga itu akan mendorong keberhasilan layanan terhadap pemangku kepentingan utama, yaitu pemerintah dan masyarakat (Kaplan \& Norton, 1992, 1996; Kaplan, 2009; Niven, 2006). Disamping itu, implementasi BSC pada lembaga riset pemerintah, seperti LIPI, memiliki fungsi ganda, yaitu sebagai alat untuk mengukur kinerja lembaga agar selaras dengan sasaran strategisnya, serta sebagai alat untuk meningkatkan akuntabilitas kinerja Lembaga (Kaplan \& Norton, 1992).

Di sisi lain, BSC sebagai alat ukur kinerja mampu menyediakan instrumen untuk menangkap seberapa jauh lembaga riset pemerintah berhasil memenuhi kinerja non finansial yang tercermin melalui 3 perspektif, yaitu pemangku kepentingan, inovasi dan pembelajaran, serta proses bisnis internal, dengan tetap memperhatikan aspek finansial yang tercermin melalui perspektif keuangan berkelanjutan (Niven, 2006). Selaras dengan apa yang dikemukakan oleh Yüksel dan Coşkun (2013) bahwa dalam hal ini, model BSC mampu memosisikan sasaran strategis lembaga riset pemerintah ke dalam kerangka kerja yang lebih efektif karena sasaran strategis lembaga langsung dikaitkan dengan 4 perspektif BSC dan IKU lembaga langsung diturunkan dari sasaran strategis dimaksud. Sehingga, kegiatan yang lembaga lakukan mau tidak mau harus sejalan dengan koridor IKU yang telah ditetapkan agar sasaran strategis lembaga terpenuhi untuk masing-masing pemangku kepentingan. 
Perspektif Keuangan Berkelanjutan

- Tata Kelola Pemerintahan Yang Baik

- Nilai Reformasi Birokrasi
Perspektif Proses Bisnis Internal

- Kontribusi Daya Saing Bangsa

- Rekomendasi Kebijakan

Yang Dimanfaatkan
Perspektif Pemangku Kepentingan

- Kontribusi Daya Saing Bangsa

- Sitasi Publikasi

- HAKI \& STP Yang

Dimanfaatkan

- Pengguna Jasa

Gambar 4. Pemetaan Sasaran Strategis dan IKU LIPI 2017-2019

Sumber: Laporan Kinerja LIPI 2017

\section{PERSPEKTIF PEMANGKU KEPENTINGAN}

\begin{tabular}{|c|c|c|c|}
\hline Sasaran Strategis & Indikator & Target & Inisiatif \\
\hline \multirow[t]{3}{*}{\begin{tabular}{lr}
\multicolumn{2}{l}{ Meningkatnya } \\
kontribusi & LIPI \\
terhadap & daya \\
saing & bangsa \\
berbasis & hasil \\
penelitian &
\end{tabular}} & $\begin{array}{l}\text { 1. Jumlah sitasi atas } \\
\text { Publikasi } \\
\text { 2. Jumlah hasil } \\
\text { penelitian dan HKI } \\
\text { yang dimanfaatkan }\end{array}$ & $\begin{array}{l}142.500 \\
\text { Sitasi } \\
145 \\
\text { Buah }\end{array}$ & $\begin{array}{l}\text { Mempertahankan hasil publikasi dari sivitas LIPI } \\
\text { yang sudah tergolong baik } \\
\text { Menghasilkan penelitian yang bermanfaat bagi } \\
\text { peningkatan taraf hidup masyarakat }\end{array}$ \\
\hline & $\begin{array}{l}\text { 3. Jumlah STP/TP yang } \\
\text { termanfaatkan }\end{array}$ & $\begin{array}{c}2 \\
\mathrm{STP} / \mathrm{TP}\end{array}$ & $\begin{array}{l}\text { Mendorong peningkatan ekonomi daerah melalui } \\
\text { penerapan teknologi yang telah dihasilkan oleh } \\
\text { LIPI }\end{array}$ \\
\hline & $\begin{array}{l}\text { 4. Jumlah pengguna } \\
\text { jasa LIPI }\end{array}$ & $\begin{array}{l}45.728 \\
\text { Orang }\end{array}$ & $\begin{array}{l}\text { Melakukan promosi lebih gencar terhadap hasil } \\
\text { penelitian LIPI }\end{array}$ \\
\hline \multicolumn{4}{|c|}{ PERSPEKTIF PROSES BISNIS INTERNAL } \\
\hline Sasaran Strategis & Indikator & Target & Inisiatif \\
\hline \begin{tabular}{l}
\multicolumn{2}{l}{ Meningkatnya } \\
kontribusi LIPI \\
terhadap daya \\
saing bangsa \\
berbasis hasil \\
penelitian
\end{tabular} & $\begin{array}{l}\text { Jumlah policy paper/ } \\
\text { rekomendasi kebijakan/ } \\
\text { keputusan yang } \\
\text { dimanfaatkan }\end{array}$ & $\begin{array}{c}143 \\
\text { Naskah }\end{array}$ & $\begin{array}{l}\text { Penetapan standar minimum yang harus dipenuhi } \\
\text { dalam pelaksanaan penelitian untuk menghasilkan } \\
\text { penelitian berkualitas tinggi }\end{array}$ \\
\hline
\end{tabular}

PERSPEKTIF INOVASI DAN PEMBELAJARAN

\begin{tabular}{|c|c|c|c|}
\hline Sasaran Strategis & Indikator & Target & Inisiatif \\
\hline $\begin{array}{l}\text { Meningkatnya } \\
\text { kontribusi LIPI } \\
\text { terhadap daya } \\
\text { saing bangsa } \\
\text { berbasis hasil } \\
\text { penelitian }\end{array}$ & $\begin{array}{l}\text { Peringkat LIPI di } \\
\text { Webometrics }\end{array}$ & $\begin{array}{l}140 \\
\text { Peringkat }\end{array}$ & $\begin{array}{l}\text { Mendorong utilisasi sumber daya berwujud berupa } \\
\text { laboratotium riset untuk meningkatkan kuantitas } \\
\text { hasil penelitian yang aplikatif }\end{array}$ \\
\hline $\begin{array}{l}\text { Terwujudnya } \\
\text { tata kelola } \\
\text { pemerintahan } \\
\text { yang baik }\end{array}$ & $\begin{array}{l}\text { Peningkatan Jumlah } \\
\text { Peneliti Nasional }\end{array}$ & $\begin{array}{c}250 \\
\text { Orang }\end{array}$ & $\begin{array}{l}\text { Meningkatkan kapasitas peneliti di lingkungan LIPI } \\
\text { maupun di institusi lain }\end{array}$ \\
\hline
\end{tabular}


PERSPEKTIF KEUANGAN BERKELANJUTAN

\begin{tabular}{llcl}
\hline Sasaran Strategis & Indikator & Target & \multicolumn{1}{c}{ Inisiatif } \\
\hline $\begin{array}{l}\text { Terwujudnya } \\
\text { tata kelola }\end{array}$ & Nilai Reformasi Birokrasi & 78 & Implementasi program kerja yang berdampak \\
$\begin{array}{l}\text { pemerintahan } \\
\text { yang baik }\end{array}$ & & Nilai & $\begin{array}{l}\text { besar pada outcome dan evaluasi berkala terhadap } \\
\text { pelaksanaan reformasi birokrasi }\end{array}$ \\
\hline
\end{tabular}

Tabel 2. Pemetaan Hasil Capaian Kinerja LIPI Berbasis BSC Sumber: Laporan Kinerja LIPI 2017

\subsection{Kunci Sukses Implementasi BSC pada LIPI}

Dua faktor utama yang paling berkontribusi terhadap keberhasilan implementasi BSC pada organisasi sektor publik, yaitu memodifikasi konsep BSC agar sesuai dengan kebutuhan organisasi; serta sistem pembelajaran yang tepat bagi pegawai, baik sebelum menerapkan BSC dan pada saat implementasinya (Northcott \& Ma'amoraTaulapapa, 2012; Radnor \& Lovell, 2003). Chan (2004) merestui pendapat tersebut, dia pun menjelaskan bahwa bahwa konsep BSC untuk organisasi sektor publik dapat dimodifikasi dengan memasukkan perspektif kinerja yang tidak termasuk dalam kerangka konseptual BSC awal. Sementara, Kaplan dan Norton (2001a) menyarankan untuk memperluas perspektif pelanggan dengan memperhitungkan banyaknya layanan, pengguna, dan pemangku kepentingan yang berkaitan dengan organisasi sektor publik (Niven, 2006; Wisniewski \& Ólafsson, 2004). Sedikit bukti empiris yang menjelaskan tentang seperti apa bentuk modifikasi yang mesti dilakukan terhadap kerangka konseptual BSC untuk organisasi sektor publik. Namun, hasil peneltian ini mampu menjawab tantangan tersebut dengan tidak hanya menyuguhkan, bahkan juga mendefinisikan seperti apa bentuk modifikasi yang seharusnya dilakukan terhadap kerangka konseptual BSC agar selaras dengan karakteristik organisasi sektor publik yang menjadi objek studi, yaitu LIPI.

Namun, modifikasi BSC tidak semestinya hanya berhenti sampai di situ saja. Northcott dan Ma'amora-Taulapapa (2012) secara lantang menegaskan bahwa setiap organisasi sektor publik harus tetap melakukan pengembangan yang berkelanjutan terhadap sistem BSC-nya karena semakin berpengalaman suatu organsasi menggunakan BSC sebagai alat pengukuran kinerja, semakin mudah organisasi tersebut menyediakan platform untuk pembelajaran BSC di masa depan. Sebagai contoh, suatu pemerintah daerah mulai menggunakan BSC di satu unit kerja. Kemudian, unit kerja tersebut mengambil pendekatan tambahan untuk mengimplementasikan BSC sehingga unit kerja lain bisa belajar dari setiap tahap implementasi BSC di unit kerja awal. Pengalaman dan pelajaran yang bisa dipetik dari implementasi BSC di unit kerja awal dapat ditransfer via aplikasi intranet ke unit kerja lain. Contoh tersebut bukan sekedar isapan jempol semata karena hal yang sama telah terjadi di Selandia Baru sebagaimana Northcott dan Ma'amoraTaulapapa (2012) jelaskan bahwa salah satu pemerintah daerah memulai implementasi BSC di salah satu direktorat. Tidak lama setelahnya, penggunaan BSC diterapkan pada enam direktorat lainnya di pemerintah daerah tersebut. Bahkan rencana implementasi BSC secara penuh oleh seluruh direktorat di pemerintah daerah tersebut sedang dikonsultasikan bersama seluruh anggota dewan perwakilan rakyat daerah terkait. Adaptasi tanpa henti itulah kuncinya.

Beberapa studi terdahulu (Northcott \& France, 2005; Northcott \& Ma'amora-Taulapapa, 2012; Pallot, 2001; Wilson et al., 2004) menunjukkan bahwa pendekatan tambahan berbasis edukasi dan pembelajaran sangat berkontribusi terhadap keberhasilan implementasi BSC pada organisasi sektor publik. Strategi edukasi dimaksud, antara lain berupa: meneliti implementasi BSC pada organisasi lain, menjadikan praktik terbaik di negara lain sebagai acuan implementasi BSC, menghadiri seminar terkait BSC, mengadakan pendidikan dan pelatihan yang berhubungan dengan manajemen kinerja, serta meminta bantuan pendampingan dari konsultan dalam implementasi BSC pada organisasi sektor publik, khususnya LIPI.

\subsection{Tantangan Ke Depan: Pantang Mundur LIPI}

Ketika muncul pertanyaan, mengapa organisasi sektor publik tidak mau menerapkan BSC sebagai instrumen pengukuran kinerjanya? Pada dasarnya, jawaban atas pertanyaan tersebut telah terungkap melalui beberapa studi terdahulu, yaitu KwokwahYeung dan Connell (2006), Northcott dan France (2005), Northcott dan Ma'amora-Taulapapa (2012), serta Radnor dan Lovell (2003). Secara umum, hasil penelitian mereka menjelaskan bahwa tantangan terbesar dalam implementasi BSC pada organisasi sektor publik adalah adanya sistem pengukuran kinerja yang telah lama digunakan oleh organisasi tetapi tidak berbasis BSC, organisasi berukuran kecil sehingga implementasi BSC akan sangat mahal, kurangnya sumber daya untuk mendukung pengumpulan informasi yang relevan sebagai input bagi BSC, terlalu sibuk dengan masalah operasional organisasi yang lebih mendesak untuk diselesaikan ketimbang menghabiskan waktu untuk implementasi BSC, serta kurangnya dukungan manajemen puncak yang diperlukan untuk mempromosikan BSC, memaksa para bawahannya untuk menggunakan BSC, dan menyediakan sumber daya yang tepat untuk mempertahankan penggunaan BSC. Tantangan terbesar lainnya adalah kesulitan dalam mengadaptasi struktur BSC sektor swasta ke dalam konteks sektor publik. 
Di sisi lain, cara menentukan indikator kinerja yang sesuai dengan tujuan dan sasaran strategis organisasi seringkali menimbulkan permasalahan tersendiri. Kaplan dan Norton (1992, 1993) mengemukakan bahwa pemilihan indikator kinerja adalah kunci utama dalam BSC. Oleh karenanya, pemilihan indikator kinerja harus dilakukan dengan cermat dan berfokus pada informasi yang relevan dengan pelaksanaan rencana strategis. Selain itu, yang penting untuk diperhatikan juga adalah hubungan sebab-akibat antar indikator kinerja pada masing-masing perspektif BSC merupakan keunggulan utama dari sistem manajemen kinerja berbasis BSC. Hubungan sebab-akibat tersebut memungkinkan manajemen organisasi sektor publik untuk tetap fokus pada pencapaian indikator kinerja utama yang memfasilitasi adanya prediksi, pembelajaran, dan inovasi (Kaplan \& Norton, 1992; Malina, Nørreklit, \& Selto, 2007). Tidak mudah memang untuk mengidentifikasi dan menentukan seberapa besar takaran yang harus diberikan terhadap masing-masing indikator kinerja utama agar hubungan sebab-akibat antar indikator dapat muncul ke permukaan dan terlihat dengan jelas.

\section{KESIMPULAN DAN SARAN}

Penelitian ini bertujuan untuk memberikan bukti empiris terkait pengembangan model BSC untuk organisasi sektor publik, khususnya lembaga riset pemerintah setingkat kementerian, yaitu LIPI. Selain itu penelitian ini dilakukan untuk mengidentifikasi faktor-faktor yang mendukung implementasi BSC pada lembaga riset pemerintah, dan tantangan yang dihadapi apabila model BSC tersebut diimplementasikan. Penelitian ini berhasil merumuskan suatu konsep BSC yang dapat LIPI gunakan untuk mempertajam sistem manajemen kinerjanya. Faktor utama penentu kesuksesan dalam implementasi model BSC di LIPI adalah adaptasi yang berkelanjutan terhadap model BSC yang kami kembangkan untuk LIPI sesuai dengan perkembangan organisasi. Tantangan terbesarnya adalah meraih komitmen para pejabat teras LIPI agar tidak enggan menerapkan BSC demi memperbaiki kinerja dan arah tujuan organisasi ke depannya.

\section{IMPLIKASI DAN KETERBATASAN}

Berdasarkan penelitian ini, diketahui bahwa LIPI merupakan lembaga riset pemerintah yang bertangung jawab kepada Presiden melalui Kementerian Riset dan Teknologi. Karakteristik LIPI sebagai lembaga penelitian menjadikan LIPI memiliki banyak aset tidak berwujud. Aset tidak berwujud ini berupa hak kekayaan intelektual yang diperoleh melalui hasil penelitian terapan. Sumber daya tidak berwujud tersebut sulit untuk diukur capaian kinerjanya. Model pengukuran kinerja berbasis BSC yang dikembangkan melalui penelitian ini belum memasukkan aset tidak berwujud ini sebagai salah satu bagian dari 4 perspektif BSC yang ada. Sehingga, penelitian selanjutnya dapat mengangkat isu ini untuk ditelaah lebih dalam agar dapat mengakomodir kebutuhan terhadap pengukuran kinerja aset tidak berwujud di lembaga penelitian.

\section{DAFTAR PUSTAKA}

Aidemark, Lars-Goan. (2001). The Meaning of Balanced Scorecards in the Health Care Organisation. Financial Accountability and Management, 17(1), 23-40. https://doi.org/10.1111/14680408.00119

Aidemark, Lars-Göran, \& Funck, E. K. (2009). Measurement and Health Care Management. Financial Accountability \& Management, 25(2), 253-276. https://doi.org/10.1111/j.14680408.2009.00476.x

Arnaboldi, M., \& Lapsley, I. (2004). Modern costing innovations and legitimation: A health care study. Abacus, 40(1), 1-20. https://doi.org/10.1111/j.14676281.2004.00143.x

Arnaboldi, M., Lapsley, I., \& Steccolini, I. (2015). Performance Management in the Public Sector: The Ultimate Challenge. Financial Accountability \& Management, 31(1), 1-22. https://doi.org/10.1111/faam.12049

Balabonienè, I., \& Večerskienè, G. (2015). The Aspects of Performance Measurement in Public Sector Organization. Procedia - Social and Behavioral Sciences, 213, 314-320. https://doi.org/10.1016/j.sbspro.2015.11.544

Boston, J., Martin, J., Pallot, J., \& Walsh, P. (1996). Public Management: The New Zealand Model. Auckland: Oxford University Press.

Bourne, M., Kennerley, M., \& Franco-Santos, M. (2005). Managing through measures: a study of impact on performance. Journal of Manufacturing Technology Management, 16(4), 373-395. https://doi.org/10.1108/17410380510594480

Braam, G. J. M., Benders, J., \& Heusinkveld, S. (2007). The balanced scorecard in The Netherlands. Journal of Organizational Change Management, 20(6), 866-879. https://doi.org/10.1108/09534810710831064

Bryson, J. M. (2004). Strategic Planning for Public and Nonprofit Organizations: A Guide to Strengthening and Sustaining Organizational Achievement (3rd ed.). San Francisco: JosseyBass: WIley.

Bryson, J. M. (2010). The Future of Public and Nonprofit Strategic Planning in the United States: The Past as Prelude. Public Administration Review, 70(December),

246-254. 
https://doi.org/10.2307/40984136

Bryson, J. M., Crosby, B. C., \& Bryson, J. K. (2009). Understanding Strategic Planning and the Formulation and Implementation of Strategic Plans as a Way of Knowing: The Contributions of Actor-Network Theory. International Public Management Journal, 12(2), 172-207. https://doi.org/10.1080/10967490902873473

Budiarso, A. (2013). Implementing The BSC Approach In Response To Structural Policy Challange In Indonesia: A Case Study Of The Ministry of Finance's Leadership Perspective. Kajian Ekonomi Dan Keuangan, 17(December), 251282.

Butler, A., Letza, S. R., \& Neale, B. (1997). Linking the Balanced Scorecard to Strategy. Long Range Planning, 30(2), 242-253. https://doi.org/10.1016/s0024-6301(96)001161

Chan, Y. C. L. (2004). Performance measurement and adoption of balanced scorecards: A survey of municipal governments in the USA and Canada. International Journal of Public Sector Management, 17(2-3), 204-221. https://doi.org/10.1108/09513550410530144

Chang, L. (2007). The NHS performance assessment framework as a balanced scorecard approach. International Journal of Public Sector Management, 20(2), 101-117. https://doi.org/10.1108/09513550710731472

Chow-Chua, C., \& Goh, M. (2002). Framework for evaluating performance and quality improvement in hospitals. Managing Service Quality: An International Journal, 12(1), 54-66. https://doi.org/10.1108/09604520210415399

Chow, C. W., Ganulin, D., Haddad, K., \& Williamson, J. (1998). The balanced scorecard: A potent tool for energizing and focusing healthcare organization management. Journal of Healthcare Management, 43(3), 263-280.

Cohen, S., Thiraios, D., \& Kandilorou, M. (2008). Performance parameters interrelations from a balanced scorecard perspective: An analysis of Greek companies. Managerial Auditing Journal, 23(5), 485-503. https://doi.org/10.1108/02686900810875307

Creswell, J. W. (2014). Research design: qualitative, quantitative, and mixed methods approaches (4th ed). Thousand Oaks,CA: SAGE Publications, Inc.

Davis, S., \& Albright, T. (2004). An investigation of the effect of Balanced Scorecard implementation on financial performance. Management Accounting Research, 15, 135-153. https://doi.org/10.1016/j.mar.2003.11.001

Denzin, N. K., \& Lincoln, Y. S. (2017). The SAGE Handbook of Qualitative Research. New Jersey: SAGE Publications Inc.

Fernandez, D., Zainol, Z., \& Ahmad, H. (2017). The impacts of ERP systems on public sector organizations. Procedia Computer Science, 111, 31-36.

https://doi.org/10.1016/j.procs.2017.06.006

Flick, U. (2007). Managing Quality in Qualitative Research. In Qualitative Research Kit (Fifth). New Jersey: SAGE Publications Inc.

Flick, U. (2019). The Concepts of Qualitative Data: Challenges in Neoliberal Times for Qualitative Inquiry. Qualitative Inquiry, 25(8), 713-720. https://doi.org/10.1177/1077800418809132

Greatbanks, R., \& Tapp, D. (2007). The impact of balanced scorecards in a public sector environment: Empirical evidence from Dunedin City Council, New Zealand. International Journal of Operations and Production Management, 27(8), 846-873. https://doi.org/10.1108/01443570710763804

Griffiths, J. (2003, December). Balanced Scorecard Use in New Zealand Government Departments and Crown Entities. Australian Journal of Public Administration, Vol. 62, pp. 70-79. https://doi.org/10.1111/j..2003.00350.x

Gunarsih, T., Saleh, C., Syukron D. W., N., \& Deros, B. M. (2016). A hybrid balanced scorecard and system dynamics for measuring public sector performance. Journal of Engineering Science and Technology, 11, 65-86.

Hood, C. (1995). The 'new public management' in the 1980s: Variations on a theme. Accounting, Organizations and Society, 20(2-3), 93-109. https://doi.org/10.1016/0361-3682(93)E0001-W

Hoque, Z., \& James, W. (2000). Linking Balanced Scorecard Measures to Size and Market Factors: Impact on Organizational Performance. Journal of Management Accounting Research, 12(1), 117. https://doi.org/10.2308/jmar.2000.12.1.1

Inamdar, N., \& Kaplan, R. S. (2002). Applying the Balanced Scorecard in Healthcare Provider Organizations. Journal of Healthcare Management, 47(3), 179-195. https://doi.org/10.1097/00115514-20020500000008

Ittner, C. D., Larcker, D. F., \& Randall, T. (2003). 
Performance implications of strategic performance measurement in financial services firms. Accounting, Organizations and Society, 28(7-8),

715-741. https://doi.org/10.1016/S0361-3682(03)000333

Jackson, A., \& Lapsley, I. (2003). The diffusion of accounting practices in the new 'managerial' public sector. International Journal of Public Sector Management, 16(4-5), 359-372. https://doi.org/10.1108/09513550310489304

Johnson, H. T., \& Kaplan, R. S. (1987). The Rise and Fall of Management Accounting. IEEE Engineering Management Review, 15(3), 36-44. https://doi.org/10.1109/EMR.1987.4306297

Jones, R., \& Pendlebury, M. (2010). Public Sector Accounting (Sixth). Essex: Pearson Education Ltd.

Kald, M., \& Nilsson, F. (2000). Performance measurement at Nordic companies. European Management Journal, 18(1), 113-127. https://doi.org/10.1016/S0263-2373(99)000742

Kaplan, R. . S., \& Norton, D. . P. (1992). The Balanced Scorecard-Measures that Drive Performance. Harvard Business Review, 18(1), 71-79. Retrieved from https://hbr.org/1992/01/thebalanced-scorecard-measures-that-driveperformance-2

Kaplan, R. S. (2009). Conceptual Foundations of the Balanced Scorecard. In Handbooks of Management Accounting Research (No. 10-074; Vol. 3). https://doi.org/10.1016/S17513243(07)03003-9

Kaplan, R. S., \& Norton, D. P. (1993). Putting the Balanced Scorecard to Work. Harvard Business Review, 3. Retrieved from www.hbr.org

Kaplan, R. S., \& Norton, D. P. (1996). Linking the balanced scorecard to strategy. California Management Review, 39(1), 53-79. https://doi.org/10.2307/41165876

Kaplan, R. S., \& Norton, D. P. (2001a). The StrategyFocused Organization: How Balanced Scorecard Companies Thrive in The New Business Environtment. Boston: Harvard Business School Publishing Corporation.

Kaplan, R. S., \& Norton, D. P. (2001b). Transforming the Balanced Scorecard from Performance Measurement to Strategic Management: Part I THE BALANCED SCORECARD EMERGES. Accounting Horizons, 15(1), 87-104. Retrieved from

http://citeseerx.ist.psu.edu/viewdoc/download? doi=10.1.1.335.2005\&rep=rep1\&type=pdf

Kollberg, B., \& Elg, M. (2011). The practice of the Balanced Scorecard in health care services. International Journal of Productivity and Performance Management, 60(5), 427-445. https://doi.org/10.1108/17410401111140374

Kwokwah-Yeung, A., \& Connell, J. (2006, July 1). The Application of Niven's Balanced Scorecard in a Not-For-Profit Organization in Hong Kong: What Are the Factors for Success? Journal of Asia Business Studies, Vol. 1, pp. 26-33. https://doi.org/10.1108/15587890680001302

Lapsley, I., \& Wright, E. (2004). The diffusion of management accounting innovations in the public sector: A research agenda. Management Accounting Research, 15(3), 355-374. https://doi.org/10.1016/j.mar.2003.12.007

Libby, T., Salterio, S. E., \& Webb, A. (2004). The Balanced Scorecard: The Effects of Assurance and Process Accountability on Managerial Judgment. The Accounting Review, 79(4), 1075-1094.

Lipe, M. G., \& Salterio, S. (2002). A note on the judgmental effects of the balanced scorecard's information organization. Accounting, Organizations and Society, 27(6), 531-540. https://doi.org/10.1016/S0361-3682(01)000599

Malina, M. A., Nørreklit, H. S. O., \& Selto, F. H. (2007). Relations among measures, climate of control, and performance measurement models. Contemporary Accounting Research, 24(3), 935982. https://doi.org/10.1506/car.24.3.10

Markless, S., \& Streatfield, D. (2001). Developing performance and impact indicators and targets in public and education libraries. International Journal of Information Management, 21(2), 167$179 . \quad$ https://doi.org/10.1016/S02684012(01)00008-1

McAdam, R., \& Walker, T. (2003). An inquiry into balanced scorecards within best value implementation in UK local government. Public Administration, 81(4), 873-892. https://doi.org/10.1111/j.00333298.2003.00375.x

Miles, M. B., Huberman, A. M., \& Saldaña, J. (2014). Qualitative Data Analysis: A Methods Sourcebook (Third). New Jersey: SAGE Publications, Inc.

Modell, S. (2004). Performance Measurement Myths in the Public Sector: A Research Note. Financial Accountability and Management, 20(1), 39-55. https://doi.org/10.1111/j.1468-

0408.2004.00185.x 
Narutomo, T. (2012). Penerapan Balance Scorecard untuk Badan Penelitian dan Pengembangan Kementerian Dalam Negeri. Jurnal Bina Praja, 04(03), 189-200. https://doi.org/10.21787/JBP.04.2012.189-200

Neely, A. (2005). The evolution of performance measurement research: Developments in the last decade and a research agenda for the next. International Journal of Operations and Production Management, 25(12), 1264-1277. https://doi.org/10.1108/01443570510633648

Niven, P. R. (2006). Balanced scorecard step-by-step: maximizing performance and maintaining results (Second). https://doi.org/10.1108/mbe.2004.26708aae.00 3

Niven, P. R. (2008). Balanced scorecard step-by-step for government and nonprofit agencies (Second). New Jersey: John Wiley \& Sons.

Nor, W. (2012). Penerapan Balanced Scorecard Pada Pemerintah Daerah. AUDI: Jurnal Akuntansi Dan Bisnis, 7(2), 280-292.

Northcott, D., \& France, N. (2005). The Balanced Scorecard in New Zealand Health Sector Performance Management: Dissemination to Diffusion. Australian Accounting Review, 15(37), 34-46. https://doi.org/10.1111/j.18352561.2005.tb00301.x

Northcott, D., \& Ma'amora-Taulapapa, T. (2012). Using the balanced scorecard to manage performance in public sector organizations. International Journal of Public Sector Management, 25(3), 166-191.

https://doi.org/10.1108/09513551211224234

Nurcholis, M. A., Satria, A., \& Maulana, A. (2017). Strategy Implementation Based Balanced Scorecard to Improve Performance of the Ministry of Marine Affairs and Fisheries. Jurnal Ekonomi \& Kebijakan Publik, 8(2), 71-85.

Pallot, J. (2001). Transparency in local government: Antipodean initiatives. European Accounting Review, 21(1), 645-660. https://doi.org/10.1080/09638180126794

Perera, S., McKinnon, J. L., \& Harrison, G. L. (2003). Diffusion of transfer pricing innovation in the context of commercialization - A longitudinal case study of a government trading enterprise. Management Accounting Research, 14(2), 140$164 . \quad$ https://doi.org/10.1016/S10445005(03)00023-4

Pidd, M. (2005). Perversity in public service performance measurement. International
Journal of Productivity and Performance Management, 54(5-6), 482-493. https://doi.org/10.1108/17410400510604601

Poister, T. H., \& Streib, G. (1999). Performance Measurement in Municipal Government: Assessing the State of the Practice. Public Administration Review, 59(4), 325. https://doi.org/10.2307/3110115

Rabbani, F., Jafri, S. M. W., Abbas, F., Pappas, G., Brommels, M., \& Tomson, G. (2007, September). Reviewing the application of the balanced scorecard with implications for low-income health settings. Journal for Healthcare Quality : Official Publication of the National Association for Healthcare Quality, Vol. 29, pp. 21-34. https://doi.org/10.1111/j.19451474.2007.tb00210.x

Radnor, Z., \& Lovell, B. (2003). Success factors for implementation of the balanced scorecard in a NHS multi-agency setting. International Journal of Health Care Quality Assurance, 16(2), 99-108. https://doi.org/10.1108/09536860310465618

Striteska, M. (2012). Key Features of Strategic Performance Management Systems in Manufacturing Companies. Procedia - Social and Behavioral Sciences, 58, 1103-1110. https://doi.org/10.1016/j.sbspro.2012.09.1091

Tanone, R., Manongga, D., \& Tambotoh, J. (2013). Sistem Pemantau Kinerja Berbasis Balanced Scorecard: Studi Kasus Uksw Dalam Rangka Mewujudkan Research University. Baca: Jurnal Dokumentasi Dan Informasi, 34(2), 167-182. https://doi.org/10.14203/j.baca.v34i2.179

Wilson, C., Hagarty, D., \& Gauthier, J. (2004). Results using the balanced scorecard in the public sector. Journal of Corporate Real Estate, 6(1), 53-64. https://doi.org/10.1108/14630010410812234

Wisniewski, M., \& Ólafsson, S. (2004). Developing balanced scorecards in local authorities: a comparison of experience. International Journal of Productivity and Performance Management, 53(7), 602-610. https://doi.org/10.1108/17410400410561222

Yin, R. K. (1977). Production efficiency versus bureaucratic self-interest: Two innovative processes? Policy Sciences, 8(4), 381-399. https://doi.org/10.1007/BF01727406

Yin, R. K. (1981). Life Histories of Innovations: How New Practices Become Routinized. Public Administration Review, 41(1), 21. https://doi.org/10.2307/975720

Yin, R. K. (2009). Introduction. In Case study research: 
design and methods (Fourth Edi, pp. 3-21). Thousand Oaks,CA: SAGE Publications, Inc.

Yin, R. K. (2014). Studi Kasus: Desain dan Metode (Empat Bela). Depok: Rajawali Press.

Yin, R. K. (2018). Case study research and applications : design and methods (Sixth). Los Angeles: SAGE Publications, Inc.

Yin, R. K., \& Kaftarian, S. J. (1997). Introduction: Challenges of community-based program outcome evaluations. Evaluation and Program Planning, 20(3), 293-297. https://doi.org/10.1016/S0149-7189(97)000086

Yin, R. K., \& Lucas, W. A. (1973). Decentralization and alienation. Policy Sciences, 4(3), 327-336. https://doi.org/10.1007/BF01435128

Yüksel, H., \& Coşkun, A. (2013). Strategy Focused Schools: An Implementation of the Balanced Scorecard in Provision of Educational Services. Procedia - Social and Behavioral Sciences, 106, 2450-2459.

https://doi.org/10.1016/j.sbspro.2013.12.282 